\title{
Quality reassessment using water quality indices and hydrochemistry of groundwater from the Basement Complex section of Kaduna Basin, NW Nigeria
}

\author{
Saadu Umar Wali ${ }^{1}$ [D $\cdot$ Noraliani Alias ${ }^{1} \cdot$ Sobri Bin Harun ${ }^{1}$
}

Received: 8 July 2020 / Accepted: 16 September 2020 / Published online: 28 September 2020

(c) Springer Nature Switzerland AG 2020

\begin{abstract}
Water quality indices allow for defining the acceptable limits for water usage. This paper evaluates the suitability of water for industrial and domestic uses. Hydrogeochemical data were derived from previous studies and exposed to an internal consistency test. Groundwater was classified using physicochemical parameters and water quality indices. Multivariate analysis (factor and clustering analyses) was applied to identify the sources of ions and classify groundwater. Similarly, regression analysis was used to model the hydrochemistry of the study area. Results indicated groundwater of varying quality based on hardness, TDS, EC, chloride, and nitrate. Groundwater classification based on the Chadha diagram revealed a $\mathrm{Na}-\mathrm{HCO}_{3}$ water type in the Kudenda-Nassarawa area. Kaduna South and Kakuri and its Environs have a $\mathrm{Ca}-\mathrm{Mg}-\mathrm{Cl}$ water type. Calcium, $\mathrm{Mg}, \mathrm{Na}$, and TDS constituted the major elements influencing the hydrochemistry of groundwater based on regression analysis. Factor analysis showed that aquifers are strongly influenced by rock weathering. Also, cluster analysis revealed different types of water sources based on their hydrogeochemical characteristics. The results of multivariate analysis concurred with Gibb's model. However, groundwater is unsuitable for industrial use since it is undersaturated with calcium carbonate. Thus, water treatment is required to avoid serious corrosion.
\end{abstract}

Keywords Basement Complex rocks · Scale formation - Water quality index · Multivariate analysis · Regression analysis . Gibbs diagram

\section{Introduction}

Groundwater quality appraisal using water quality indices (WQIs) is essential for managing water quality [1-6]. The use of WQIs for appraisal of groundwater aptness for drinking and industrial uses in developing countries is required. There is an unprecedented increase in anthropogenic activities that are harmful to water quality. These include urbanization, industrialization, and irrigation farming. The WQIs were established for a rating of sources of water supply in a user-friendly format and easily understandable design. It allows for defining the acceptable limits for water usage. By design, WQIs reduce information on hydrochemical data and provide a summary of hydrochemical data that failed to comply with a certain index. Thus, water quality indices are typically beneficial for comparative analysis and overall inquiries relating to water quality and population vulnerability [7]. Concerns about different hydrochemical characteristics consequent of variation in geology and geography are possible and require the application of WQIs [8]. Water quality comprises the esthetic, radiological, biological, chemical, and physical qualities of the water $[9,10]$. The evaluation of groundwater quality is beneficial owing to increasing demand and

\footnotetext{
$\triangle$ Saadu Umar Wali, saadu.umar@graduate.utm.my; Noraliani Alias, noraliani@utm.my; Sobri Bin Harun, sobriharun@utm.my| ${ }^{1}$ Department of Water and Environmental Engineering, School of Civil Engineering, Faculty of Engineering, Universiti Teknologi Malaysia, 81310 UTM Skudai, Johor, Malaysia.
} 
degradation of groundwater aquifers in emerging economies and pollutant generation from multiple sources such as industry, agriculture, and urban discharges. The water quality of aquifers can be weighed using individual water quality parameters. It is currently declining since it involves computations of a lot of concentrations of hydrochemical parameters. Many countries prefer the application of a WQI. This enables the appraisal of water quality status. It is easy to comprehend as a single rated parameter [10].

Individual countries and agencies have incorporated various parameters of water quality to create local WQI. Most of the indices created are built on the American National Sanitation Foundation index [10]. Hydrochemical analysis of groundwater using WQI is widely conducted in many parts of the world. The evaluation of nitrate pollution in groundwater and its impending health hazards indicate that $61 \%$ of groundwater sources have $\mathrm{NO}_{3}$ concentrations exceeding WHO reference guidelines in the Nagpur region of southern India [11]. Sources of drinking water were slightly alkaline. The values of WQI vary between 92 and 295 . Also, $86 \%$ of groundwater sources fall in poor water quality class [11]. Weathering of bedrock and anthropogenic activities have rendered shallow aquifers near Kaduna Refinery unsuitable for drinking, due to the migration of effluents from petrochemicals and landfills [12]. Leaching of $\mathrm{HCO}_{3}$ was the major mechanism aiding arsenic mobilization in $\mathrm{HCO}_{3}$ assertive aquifers in Bangladesh [13]. Hydrochemical analysis of shallow groundwater in Kakuri and its Environs by Anudu, Obrike [14] discovered water of good quality for drinking.

Seasonal assessment of WQI from the River Kolong, India, by Bora and Goswami [15], revealed more deterioration of water quality during monsoon. Mean WQI varied between 85.73 and 80.75 in pre- and post-monsoon, respectively. Significant temporal variability with high concentrations of $\mathrm{NO}_{3}, \mathrm{SO}_{4}$, and $\mathrm{Ca}$ was reported from the Pocheon spa region of South Korea [16]. It suggested the impact of surface processes. The evaluation of groundwater quality during post-monsoon indicates that $90 \%$ of water sources are appropriate for drinking. In contrast, the percentage declined to $60 \%$ during monsoon [17]. Water quality appraisal from Kaduna, Kafancan, and Zaria indicate no radium and thorium could be trace from the study area. However, $\mathrm{Cd}, \mathrm{Ni}, \mathrm{COD}$, and $\mathrm{pH}$ concentrations were above the WHO reference guidelines [18]. Groundwater quality assessment from some villages in northern India indicates the unsuitability of groundwater due to high levels of hardness, F, Ca, and Mg [19]. The content of calcium carbonate renders aquifers unsuitable for industrial use since $\mathrm{CaCO}_{3}$ precipitates easily. In Kanavi Halla basin India, two-third of groundwater sources fall in poor to very poor class based on WQI [20]. The heavy metal pollution index $(\mathrm{HPI})$ revealed severe pollution from a gold mine in east Cameroon [21]. A good water based on WQI was revealed from Karacaoren Dam. Poor and very poor water quality occurred in the northern and southern portions of the basin. Water quality in the study area was impacted by the diffusion of in situ pollutants in the Aksu River Basin SW Turkey [22]. Groundwater contaminants were derived primarily from anthropogenic activities in the Lower Yangtze Delta in China. Groundwater suitability for industrial and domestic uses can be guaranteed after the removal of high ions and toxic metals [23]. The water of better quality occurred during post-monsoon compared to premonsoon as a result of groundwater recharge in the Bay of Bengal, India [24].

Despite the tremendous research works on groundwater quality in Kaduna Basin [25-30], these studies are characterized by reports on individual physicochemical elements of water quality, instead of the application of WQI for the appraisal of the quality status of aquifers. Studies around the world are increasingly employing water quality indices $[10,11,15,20,22,31-36]$, for the evaluation of groundwater suitability for drinking. Appraisal of the quality status of groundwater using WQI helps to classify groundwater sources and became an essential topic in third world nations; hence, continuous monitoring of sources of drinking water is important. This is due to anthropological activities (mainly effluents from industry, agriculture, and municipal sources) that are harmful to groundwater quality. This study seeks to evaluate the hydrochemistry of groundwater using WQIs in the Kaduna Basin.

\section{The study area}

\subsection{1. Location and climate}

Kaduna Basin is situated between latitude $9^{\circ} 30 \mathrm{~N}-11^{\circ} 45 \mathrm{~N}$ and longitude $7^{\circ} 03 \mathrm{E}-8^{\circ} 30 \mathrm{E}$ (Fig. 1). It covers a total area of $21,065 \mathrm{sq} \mathrm{km}$. It is drained by Rivers Galma, Kubanni, and Tubo which formed the major tributaries to River Kaduna [37]. Kaduna Basin rests on the 'High Plains' of northern Nigeria reaching up to $670 \mathrm{~m}$ above sea level at some locations. The basin is in Guinea Savannah Zone, with both wet and dry seasons. Rainfall season prevails from May to October. The average annual precipitation is above $2000 \mathrm{~mm}$. During the dryer years, it can be as low as $300 \mathrm{~mm}$ (Fig. 2a). The difference between the wettest and driest month in terms of precipitation is $279 \mathrm{~mm}$. The long-term average is $1000 \mathrm{~mm}$ [37]. The annual variation of temperature is $3.8^{\circ} \mathrm{C}$ (Fig. 2b). The dry spells last from November to April. It is characterized by low temperatures during Harmattan (December-February). Very dry and hot weather is prevalent from March to April. Mean diurnal temperature can 


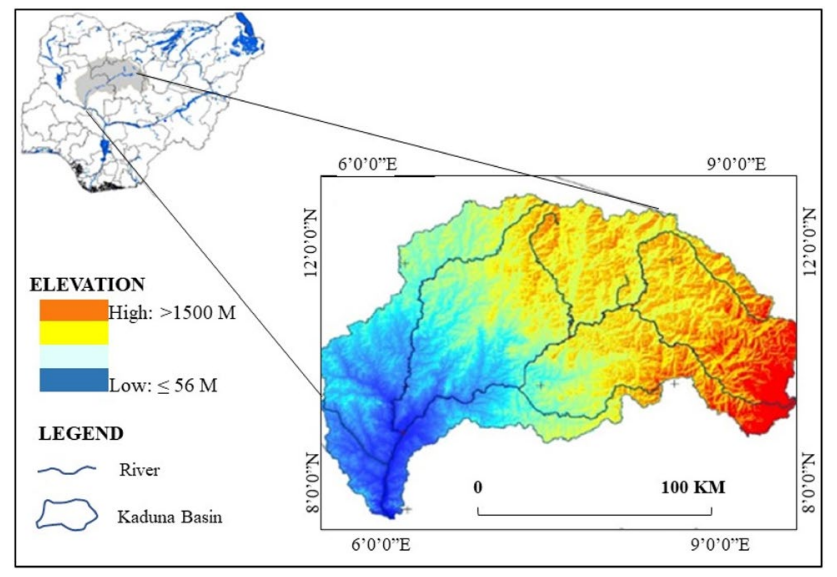

Fig. 1 Map of the Kaduna Basin. After Okafor and Ogbu [38]

attain $27^{\circ} \mathrm{C}$. The relative humidity is high throughout the rainy season. It decreases during the dry spells.

\subsection{Geology and hydrogeology}

Kaduna Basin consists of crystalline basement complex (CBC) rocks. These are mainly of granitic gneisses, migmatites, and biotite types. Rebooted metasediments formed the magnetite gneiss complex. It is characterized by various structures and textures. Batholiths and younger granites are noticeable southwestwards. Severe chemical weathering and fluvial erosion shaped by the environmental bioclimatic scenery of the region have formed a conspicuous high-pitched undulating flatland as well as soothing interfluves. Weathered or metamorphic rocks are dominant. The normal rock type is a gneiss-migmatite complex that outcropped along the Kaduna-Zaria axis [37]. Metasedimentary rock series consisting of interchangeable rocks including gneiss, pegmatites, schist, and quartz are noticeable (Fig. 3), mainly comprised of decayed sedimentary and metavolcanics rocks. Marvelous boulders of well-outlined migmatites in the northeast-southwest bloc and west of the Kaduna area are noticeable. The ubiquitous batholiths in the southern parts of Kaduna are characterized by exposed plutonic rocks [37]. These batholiths
Fig. 2 a Temperature and $\mathbf{b}$ rainfall (Climate-Data.Org: https://en.climate-data.org/ africa/nigeria/taraba/kadun a-lissam-385152/. Retrieved on $12 / 02 / 2020)$
Fig. 3 Theorized geological cross section of the groundwater flow in the Kaduna Basin
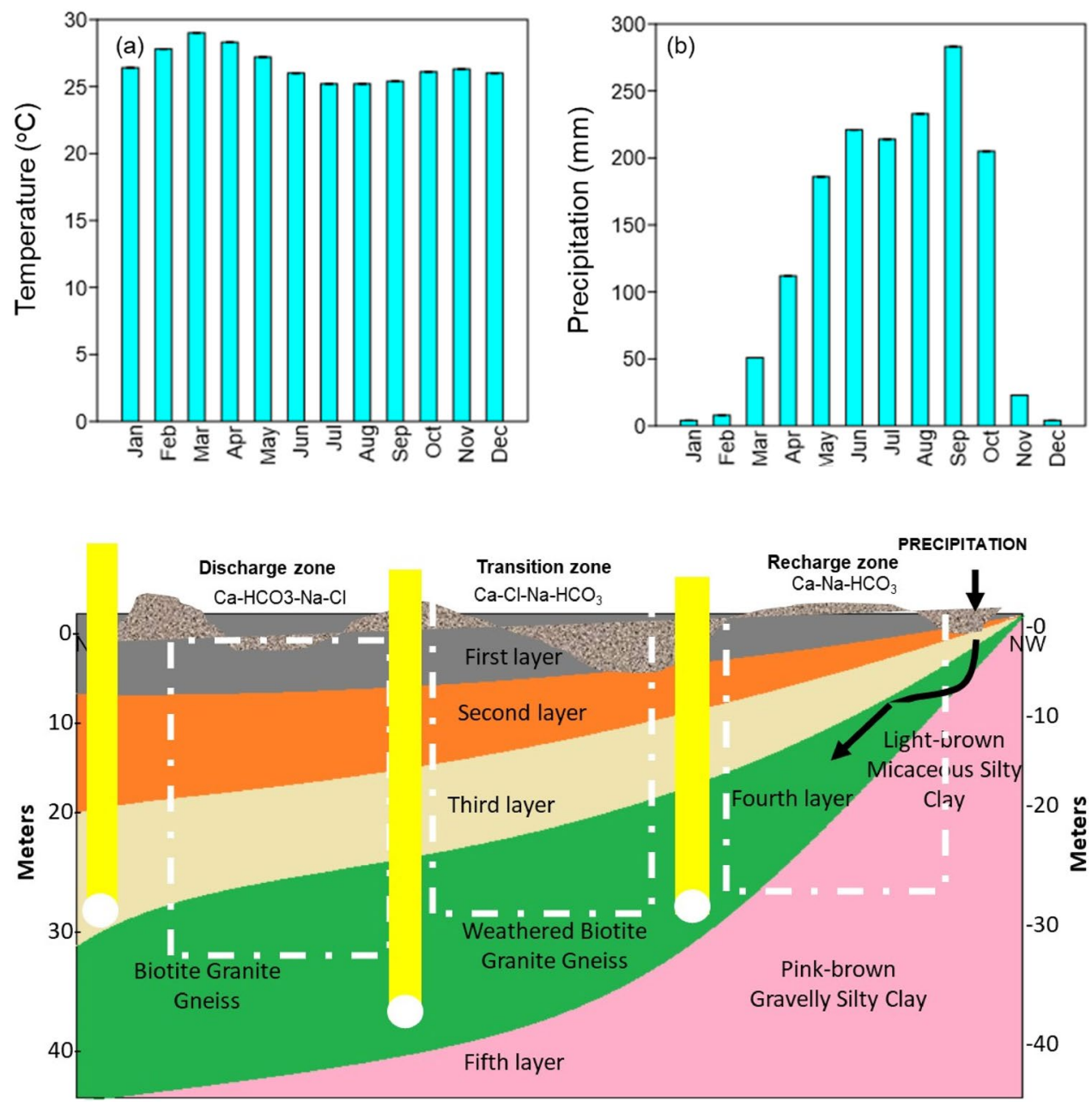

SN Applied Sciences A SPRINGER NATURE journal 
mainly comprise of granodiorites, charnockites, granites, monthonites, diorites, and leucocratic-porphyritic granites. Some sections are coated by laterites that are sporadically fused especially the battered exteriors into lateritic knobs pied with silty and sandy clays [37].

Over $80 \%$ of the study area is enclosed by the CBC. The fresh alluvium of the River Niger and Nupe Sandstone make up 20\% [39]. The hydrogeological specifications of the basin are characteristic of Nigeria's Basement Complex areas [40-42]. Previous assessment of hydrogeological conditions in the basin showed that at least $30 \%$ of boreholes were not productive. Borehole yields varied between 0.2 and $1 \mathrm{lit} / \mathrm{sec}$. Although a 30\% borehole failure was documented, even the productive wells were not promising, thus illustrating the gratuitous hydrogeological condition of Nigeria's Basement Complex [39]. Ten percent of the Kaduna Basin is covered by sedimentary formations of the Nupe Sandstone. The 'Newer basalt' is evident throughout Manchok and Kafanchan areas. It adjoined the western peripheries of the north-central plateau. The basalt was formed when the plateau attained its current topography. It is marginally influenced by erosion, consequently overlaying alluvial sediments [43]. The areas of severe erosion and sandy riverbeds also rise. These are squeezed in between specific basalt deluges.

The prospect of the fluvio-volcanic aquifer shows a great water yield (370-500 $\mathrm{m}^{3} /$ day). At Tum Village (Borehole No. GWR/21/1) in the 'Newer Basalt' a great quantity of water was recorded $\left(12.6 \mathrm{~m}^{3} / \mathrm{h}\right)$. An extremely productive spring appears in the 'Newer Basalt' producing about $11,000 \mathrm{~m}^{3} /$ day at Manchok, throughout the dry season. It established the headwater of an offshoot of the Kaduna River [43]. Potential sources of pollutants like landfills ought to be located far away from probable recharge regions, consequent to the superficial depth of shallow groundwater [25]. Seasonal assessment of spring water, shallow and deep aquifers by Obada and Olaniyan [43], discovered that the superficial aquifers were polluted from anthropologic activities. Sources of pollutants include inappropriate waste disposal, seepage by septic reservoirs, and urban effluents. Although the hydrochemistry and the hydrogeology of the Kaduna Basin are detailed in the literature $[12,18,44-47]$, there is a need for further analysis of groundwater quality based on WQI.

\section{Materials and methods}

\subsection{Review procedure and data sources}

Hydrochemical data were derived from the literature following the procedure summarized in Fig. 4 and Table 1. A total of 1754 potentially important articles were identified, from Google Scholar, reducing to 3 based on extractable data on $\mathrm{pH}$, temperature, TDS, $\mathrm{EC}, \mathrm{Na}, \mathrm{Fe}, \mathrm{K}, \mathrm{Cl}, \mathrm{NO}_{3}, \mathrm{HCO}_{3}$, and $\mathrm{SO}_{4}$. This was based on the defined criteria summarized in Fig. 2. The search was limited to studies published from the year 2000 (Table 2). Data on physicochemical parameters were adopted from 52 sites [14, 26, 43]. The electrical conductivity (EC) values were not measured by Obada and Olaniyan [43]. So, the EC values were calculated using the LENNTECH converter for EC values (https://www. lenntech.com/calculators/conductivity/tdsengels.htm).

\subsection{Internal consistency test}

The internal consistency of data was tested using the chemical balance error (CBE) equation [48]. The CBE is defined thus:

$\mathrm{CBE}=\frac{\sum \text { Cations }-\sum \text { Anions }}{\sum \text { Cations }+\sum \text { Anions }} \times 100$

where the concentration of individual elements is stated in $\mathrm{meq} / \mathrm{l}$. The sums of cations (6893.09) and anions (7829.92) were substituted, Eq. 2 and 3:

$\mathrm{CBE}=\frac{\sum \text { cations }(6893.09)-\sum \text { Anions }(7829.92)}{\sum \text { Cations }(6893.09)+\sum \text { Anions(7829.92) }} \times 100$

$\mathrm{CBE}=\frac{6893.09-7829.92}{6893.09+7829.92}=\frac{-936.83}{14723.00}=-0.064 \times 100= \pm-6.40$

where the cationic and anionic concentration is fully measured, and the variance should not be more than $5 \%$. However, there are slight but more negative values greater than $5 \%( \pm-6.40)$, as a result of the lack of $\mathrm{NO}_{3}$ measurements from Kudenda-Nassarawa area. Despite the slight variance, the hydrochemical data were employed for further analysis due to the irregularity of sampling periods and locations, which may interfere with the results.

\subsection{Computation of WQI}

The WQI is a remarkable technique that offers a broader outlining of water quality conditions [10,20, 21,49,50]. It represents the magnitude that reflects the collective consequence of various physicochemical parameters. It is computed by assigning discrete weights (wi) over a scale of 1 which represents the lowest effect. The greatest impact on water quality is presented by 5 . It is built on their expected impacts on human health. Elements having serious health consequences and whose concentrations exceeding the essential limits can hamper the usability of groundwater are ranked high. High intensities of elements such as $\mathrm{NO}_{3}, \mathrm{Cl}$, and TDS were given a high-ranking weight 

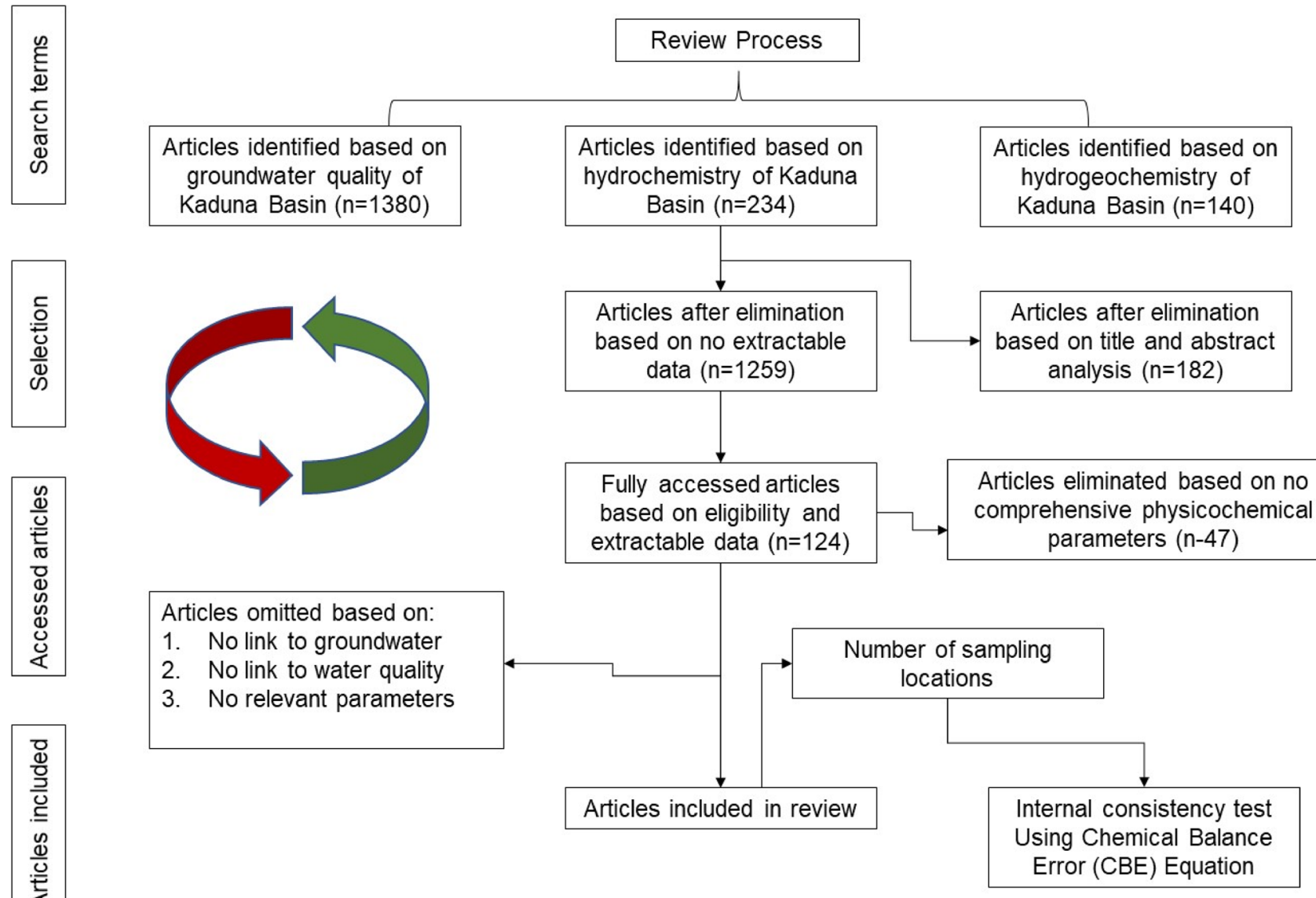

Fig. 4 Review methodology adopted for this study

Table 1 Search terms used in exploring the database and the related parameters

\begin{tabular}{|c|c|c|c|}
\hline S/no & Term classification & Search terms & $\begin{array}{l}\text { Articles } \\
\text { identi- } \\
\text { fied }\end{array}$ \\
\hline 1 & Groundwater quality Kaduna Basin & $\begin{array}{l}\text { Groundwater, aquifers, physicochemical parameters, water quality elements }(\mathrm{pH} \text {, } \\
\left.\text { temperature, } \mathrm{TDS}, \mathrm{EC}, \mathrm{Na}, \mathrm{Fe}, \mathrm{Mg}, \mathrm{Ca}, \mathrm{K}, \mathrm{Cl}, \mathrm{HCO}_{3}, \mathrm{NO}_{3}, \text { and } \mathrm{SO}_{4}\right)\end{array}$ & 1380 \\
\hline 2 & Hydrochemistry Kaduna Basin & $\begin{array}{l}\text { Groundwater, aquifers, physicochemical parameters, water quality elements ( } \mathrm{pH} \text {, } \\
\text { temperature, TDS, } \mathrm{EC}, \mathrm{Na}, \mathrm{Fe}, \mathrm{Mg}, \mathrm{Ca}, \mathrm{K}, \mathrm{Cl}, \mathrm{HCO}_{3}, \mathrm{NO}_{3} \text {, and } \mathrm{SO}_{4} \text { ) }\end{array}$ & 234 \\
\hline 3 & Hydrogeochemistry Kaduna Basin & $\begin{array}{l}\text { Groundwater, aquifers, physicochemical parameters, water quality elements }(\mathrm{pH} \text {, } \\
\left.\text { temperature, } \mathrm{TDS}, \mathrm{EC}, \mathrm{Na}, \mathrm{Fe}, \mathrm{Mg}, \mathrm{Ca}, \mathrm{K}, \mathrm{Cl}, \mathrm{HCO}_{3}, \mathrm{NO}_{3}, \text { and } \mathrm{SO}_{4}\right)\end{array}$ & 140 \\
\hline
\end{tabular}

of 5 (Table 3). Elevated $\mathrm{NO}_{3}$ concentration in drinking water is related to the blue baby syndrome. High chloride can affect the palatable taste and is injurious to plants. Variation in TDS can be an indicator of anthropogenic inputs. The intermediate elements such as $\mathrm{Ca}, \mathrm{Mg}, \mathrm{SO}_{4}$, sodium, bicarbonate, and potassium were assigned weights varying from 2 to 4 . Those that have negligible impacts like potassium were assigned the lowest weight of 1 (Table 3 ). The relative weight of physicochemical parameters, as summarized in Table 3, is estimated using Eq. 4:
$W_{i}=\frac{w_{i}}{\sum_{i=1}^{n} w_{i}}$

where $\boldsymbol{W}_{1}$ represents the relative weight, $w_{i}$ is the weight of individual elements and $n$ is the sum of the analyzed elements. The estimated $W_{i}$ values of respective elements are summarized in Table 3.

The quality ranking $\left(q_{i}\right)$ for discrete elements is given by dividing its absorption value(s) by its standard value specified by the WHO (2011). The outcome is transformed into 
Table 2 Sources of data employed for review

\begin{tabular}{|c|c|c|c|c|c|c|c|}
\hline S/no & Study & Study area & Type of data & No. of samples & Study period & Source type & References \\
\hline 1 & $\begin{array}{l}\text { Assessment of sub- } \\
\text { surface water in } \\
\text { Southern Sections } \\
\text { of Kaduna, Nigeria }\end{array}$ & Southern Kaduna & $\begin{array}{l}\text { List of evaluated } \\
\text { physical and } \\
\text { chemical param- } \\
\text { eters }\end{array}$ & $N=31$ & Not specified & Deep groundwater & [43] \\
\hline 2 & $\begin{array}{l}\text { Hydrogeochemi- } \\
\text { cal assessment of } \\
\text { subsurface water } \\
\text { from shallow wells } \\
\text { across Kakuri and } \\
\text { its surroundings, } \\
\text { Kaduna, Nigeria }\end{array}$ & $\begin{array}{l}\text { Kakuri and its sur- } \\
\text { roundings }\end{array}$ & $"$ & $N=15$ & $"$ & $\begin{array}{l}\text { Superficial subsur- } \\
\text { face water }\end{array}$ & [14] \\
\hline 3 & $\begin{array}{l}\text { Contamination of } \\
\text { groundwater from } \\
\text { septic reservoirs in } \\
\text { designated areas, } \\
\text { Kaduna, Nigeria }\end{array}$ & $\begin{array}{l}\text { Kudenda-Nassarawa } \\
\text { zone }\end{array}$ & $"$ & $N=6$ & $"$ & $"$ & [26] \\
\hline
\end{tabular}

Table 3 Relative weight of chemical parameters

\begin{tabular}{llll}
\hline Elements & WHO (2011) & $w_{i}$ & $W_{1}$ \\
\hline $\mathrm{pH}$ & $6.5-8.5$ & 4 & 0.093 \\
Temperature & Ambient & 1 & 0.023 \\
$\mathrm{EC}$ & 1000 & 5 & 0.116 \\
$\mathrm{TDS}$ & 500 & 5 & 0.116 \\
$\mathrm{Ca}$ & 75 & 2 & 0.047 \\
$\mathrm{Mg}$ & 125 & 2 & 0.047 \\
$\mathrm{Na}$ & 200 & 2 & 0.047 \\
$\mathrm{~K}$ & 12 & 1 & 0.023 \\
$\mathrm{HCO}$ & 250 & 3 & 0.070 \\
$\mathrm{Cl}$ & 250 & 5 & 0.116 \\
$\mathrm{SO}_{4}$ & 250 & 4 & 0.093 \\
$\mathrm{Fe}$ & 2 & 4 & 0.093 \\
$\mathrm{NO}_{3}$ & 50 & 5 & 0.116 \\
& & $\sum w_{i}=43.000$ & $\sum w_{i}=1.000$ \\
\hline
\end{tabular}

All absorptions are in $\mathrm{mg} / \mathrm{l}$, except $\mathrm{pH}$ (unit), temperature $\left({ }^{\circ} \mathrm{C}\right)$, and $\mathrm{EC}(\mu \mathrm{S} / \mathrm{cm})$

a fraction (mainly percentage) through multiplying by 100 . This is computed using Eq. 5:

$q_{i}=\left(\frac{C_{i}}{S_{i}}\right) \times 100$

where the quality rating is $q_{i}, C_{i}$ is the intensity of different elements in groundwater samples $(\mathrm{mg} / \mathrm{l})$ and the reference value for the individual parameter $(\mathrm{mg} / \mathrm{l})$ is $\mathrm{S}_{i}$ built on the WHO (2011) reference value. It represents $\mathrm{SI}_{i}$ value determined initially using Eq. 5, before computation of water quality index:

$\mathrm{SI}_{i}=W_{i} \times q_{i}$
$\mathrm{WQI}=\sum_{i=1}^{n} \mathrm{SI}$

where the subindex is $\mathrm{Sl}_{i}$ of the ith element and the quality rating built on the intensities of $i$ th elements is $q_{i}$. The computed values of WQI are categorized into five classes: $\mathrm{WQI}=\leq 50$ (excellent), WQI = 50-100 (good), WQ1 = 100-200 (poor), $\mathrm{WQI}=200-300$ (very poor), and $\mathrm{WQI}=>300$ (unsuitable) $[11,15,20,31-33,35,51]$. However, groundwater sources that are suitable for drinking may not necessarily be suitable for industrial use(s).

\subsection{Suitability for industrial use}

Water quality requirements vary with types of industry. Industries, such as thermal plants, boiler feed water, and beverages, require a substantial quantity of water. Good water quality capable of averting scale formation and corrosion is required by certain industries. Beverages, dairy, and brewing industries require guidelines for drinking water quality. In heavy industries, scale formation constitutes a major problem. Consequently, Langelier (1936) proposed a saturation index to determine the extent of scale formation by water. The Langelier Saturation Index (LSI) predicts the stability of $\mathrm{CaCO}_{3}$ in water and shows whether water can dissolve, precipitate, or will be stable with $\mathrm{CaCO}_{3}[10,52]$. The LSI is computed (Eq. 8), as the variance between calcium bicarbonatesaturated $\mathrm{pH}(\mathrm{pHs}$ ) and the actual pH (Eq. 9).

$\mathrm{LSI}=\mathrm{pH}($ measured $)-\mathrm{pHs}$

where

$\mathrm{pHs}=A+B-C-D$ 
The $\mathrm{pHs}, A, B, C$, and $D$ are computed following the Langelier technique. The LSI tends to be negative if the $\mathrm{pH}$ level of water is below the saturation $\mathrm{pH}$. Thus, water is expected to have low scale formation potential. The LSI tends to be positive if the initial $\mathrm{pH}$ of water is above the $\mathrm{pHs}$, indicating $\mathrm{CaCO}_{3}$-supersaturated water that has a high potential for scale formation. The greater the LSI values, the more its potential for scale formation [10, 52]. Also, a different index for quantifying $\mathrm{CaCO}_{3}$ scale formation was later developed by Ryznar [53]. The Ryznar Stability Index (RSI) helps to avoid confusion of positive saturation indices that are typically classified as non-scale forming or non-corrosive. The RSI is calculated:

$\mathrm{RSI}=2 \mathrm{pH}_{\mathrm{s}}-\mathrm{pH}$

where $\mathrm{pH}$ represents the estimated $\mathrm{pH}$ value of water and the $\mathrm{pH}_{\mathrm{s}}$ represents the $\mathrm{pH}$ at saturation point, computed using Langelier's technique. The RSI for all water types is constantly positive. The character of both treated and natural water having RSI values of 5.5 or below can have high potentials for scale formation. Water having RSI values of 9.5 tend to have a low scale formation potential, though might have acute corrosivity under high temperature [10, 52-54]. The LSI was calculated using the LSI Calculator (https://www.lenntech.com/calculators/langelier/inex/ langelier.htm).

\subsection{Statistical analysis}

\subsubsection{Factor analysis}

Factor analysis (FA) is applied to classify data for an easy explanation $[55,56]$. It is used to obtained proper evidence concerning the link between hydrogeochemical parameters and sampling spots [57]. The central objective of FA in the hydrogeochemical analysis is the classification of the hydrochemical data [48]. It involved two steps: (a) data standardization and (b) removal of factors $[56,58]$. Even though some related hydrogeochemical data are lost during the analysis, the depiction of the method is significantly reduced [56]. It is used to obtain proper evidence concerning the link between hydrogeochemical parameters and sampling spots [57]. The FA bilinear model is typically reorganized using a matrix decomposition equation:

$X=T P^{T}+E$

where the matrix of data is represented by $X$ which is reduced into $T$ (matrix score) and $P T$ (loadings matrix), plus (residual matrix $(E))$.

\subsubsection{Hierarchical clustering analysis}

Hierarchical clustering analysis (HCA) is used to categorize groundwater sources based on a raw hydrochemical data matrix in individual clusters devoid of any prior supposition. This study used the Ward's algorithmic clustering process subsequent to the Euclidean distance method. It is deemed a potent clustering procedure $[58,113]$. Before the clustering, the hydrogeochemical data $x_{j i}$ were harmonized by $Z$-scale translation as:

$Z=\frac{X_{j i}-\dot{x}_{j}}{S_{j}}$

where $x_{j i}=$ value of the $j$ th hydrochemical factor calculated at the ith location, $\dot{\mathrm{x}}_{j}=$ mean (spatial) value of the $j$ th parameter and $S_{j}=$ standard deviation (spatial) of the jth parameter.

This verification allowed for the formation of a dendrogram as a function of the sampling locations and hydrogeochemical parameters. So, employing the hydrogeochemical data into HCA is an incomparable approach. HCA simplifies data grouping assembled on similarities of the studied physicochemical parameters $[59,60]$. The FA and HCA were performed on 13 subsets of hydrogeochemical parameters. The entire analyses were performed using PAST3 (version 3.14), SPSS (version 16) and Minitab (mbt 16) statistical software packages.

\subsubsection{Regression analysis}

Regression analysis enables an understanding of the relationship between hydrochemical elements by fitting a linear equation to the hydrochemical data. Values of the separate elements $x$ are connected to a value of $y$ (i.e., dependent variable). The regression model of hydrochemical data for $p$ experimental elements $x_{1}, x_{2}, x_{3}, \ldots . x_{p}$ is expressed:

$\mu_{\gamma}=\beta_{o}+\beta_{1}+x_{1}+\beta_{2} x_{2}+\cdots+\beta_{p} x_{p}$

How the mean reaction $\mu_{\gamma}$ varies with experimental elements is defined by the regression model. The detected $y$ values tend to vary with their means $\mu_{\gamma}$ and are believed to have a similar standard deviation $\sigma$. The fitted values $b_{0} b_{1}, \ldots, b_{p}$ approximate the elements $\beta_{0}, \beta_{1}, \ldots, \beta_{p}$ of the regression model. Meanwhile, the detected $y$ value(s) differ with their mean, and the regression model contains an expression for this difference. It is defined as Data $=$ fit + residual. The term 'fit' is expressed:

$\mu_{\gamma}=\beta_{o}+\beta_{1}+x_{1}+\beta_{2} x_{2}+\cdots+\beta_{p} x_{p}$ 
The term 'RESIDUAL' is the deviation of the detected $y$ value(s) from the means $\mu_{\gamma}$. It is typically distributed with mean 0 and the variance $\sigma$. The symbol of the model is $\varepsilon$. The regression model for formally given $n$ observations is:

$y_{i}=\beta_{o}+\beta_{1} x_{i 1}+\beta_{2} x_{i 2}+\cdots+\beta_{p} x_{i p}+\varepsilon_{i}$ for $i=1,2, \ldots n$

The best-fit line and least-squares models for the hydrochemical data are computed by lessening the sum of squares of the perpendicular deviations from individual data point to the line. If a point lies exactly on the fitted line, then its perpendicular deviations $=0$. Since the aberrations are initially squared, then calculated, there are no annulments between negative and positive values. The least-squares values $b_{0} b_{1}, \ldots, b_{p}$ are typically calculated using the statistical software package(s). The fitted values using the equation $b_{0} b_{1} x_{i 1}+\cdots+b_{p} x_{i p}$ expressed as $\hat{y}_{i}$, and the residuals $e_{i}$ are equal to $y_{i}-\hat{y}_{i}$, the variance between the fitted and observed value(s). The summation of the residuals $=0$. The variance $\sigma_{2}$ maybe computed:

$S^{2}=\frac{\sum e_{i}^{2}}{n-p-1}$

It is identified as MSE, i.e., mean squared error. The computed standard error is given as $s=\sqrt{\text { MSE }}$. The statistical analysis was conducted using MINITAB (mbt 16) statistical package.

\subsection{Groundwater evolution}

The basis of dissolved ionic substances and the processes for the evolution of groundwater are revealed by the graphical procedure as an interface of TDS versus $\mathrm{Cl} /\left(\mathrm{Cl}+\mathrm{HCO}_{3}\right)$ and $\mathrm{Na} /(\mathrm{Na}+\mathrm{Ca})$ ratios $[21,61,62]$. Precipitation is the preliminary process since the chemical compositions of aquifers are affected by the volume of suspended salts/ions generated by precipitation [21, 61-64]. Naturally, the volume of precipitation is consistently high surpassing the low quantity of dissolved elements resulting from the rock mineral. Aquifers in this group occur naturally in hot and dry regions. The contrary end member to precipitation sequence consists of freshwaters obtaining their main source of suspended elements from the soils and rock mineral of their basins. This assembly specifies the successive mechanism which affects groundwater chemistry as rock dominance. The last mechanism is consisting of evaporation-fractional definition. This process produces an order of series extending from the calcium-rich water type resultant from rock weathering, to the sodium-rich high-salinity end member which is the opposing process. The mechanism shaping world water chemistry can be measured by plotting the TDS mass ratio against the $[\mathrm{Na}+\mathrm{K}] / \mathrm{Na}+\mathrm{K}+\mathrm{Ca}]$ and $[\mathrm{Cl}] /\left[\mathrm{Cl}+\mathrm{HCO}_{3}\right]$ ratios for anions and cations [61, 64]. Further, the Chadha diagram was used to classify groundwater [65-67].

\section{Results and discussion}

Table 3 and Fig. 5 present a statistical summary of hydrochemical data. Groundwater rating built on WHO (2011) reference guidelines indicated that TDS, $\mathrm{Ca}, \mathrm{Mg}$, and $\mathrm{K}$ concentrations are above the defined reference values for drinking water in the Kudenda-Nassarawa area. Though TDS is not commonly viewed as an essential pollutant; it is used as a mark of palatable attributes of drinking water and as an overall indicator of the chemical contaminants. Essential sources of TDS in aquifers include overflow from irrigated fields and private (or urban) spillover, effluent-rich mountain waters, filtering of soil sullying, and point source water contamination release from modern or polluted water treatment facilities [58, 68-73]. The most recognized chemical constituents are $\mathrm{Ca}, \mathrm{PO}_{4}, \mathrm{NO}_{3}, \mathrm{Na}, \mathrm{K}$, and $\mathrm{Cl}$, which are found in overland flow, general stormwater spillover, and overflow from street deicing salts [74-78]. Vibrant and destructive components of TDS are pesticides and other contaminants emerging from overland flow [79-81]. Elevated concentrations of $\mathrm{Ca}$ and $\mathrm{Mg}$ in aquifers are normally associated with hardness [82]. However, significant positive correlations between hardness and sodium were reported from Texas aquifers [83]. Calcium and $\mathrm{Mg}$ are particularly derived from dolomite, gypsum, and limestone. Calcium and $\mathrm{Mg}$ occur in vast amounts in saltwater $[84,85]$.

Magnesium is the primary cause of the hardness and scale-forming properties of water. It is imperative to understand that other factors including $\mathrm{pH}$, temperature, supersaturation, and flow velocity can influence scale formation [86]. Groundwater sources that have low $\mathrm{Ca}$ and $\mathrm{Mg}$ are required in manufacturing, coloring, tanning, and electroplating [86-88]. Calcium functions as a stabilizer for $\mathrm{pH}$, owing to its buffering properties. Calcium can react with water even at a room temperature based on the mechanism defined in Eq. 17.

$\mathrm{Ca}(\mathrm{s})+2 \mathrm{H}_{2} \mathrm{O}(\mathrm{g}) \rightarrow \mathrm{Ca}(\mathrm{OH})_{2}(\mathrm{aq})+\mathrm{H}_{2}(\mathrm{~g})$

Consequently, dissolved calcium hydroxide in the form of hydrogen gas and soda is formed. Erosion reaction is another critical reaction mechanism. It is triggered by the presence of $\mathrm{CO}_{2}$, resulting in the formation of carbonic acid. This can alter $\mathrm{Ca}$ compounds. Carbon weathering reaction mechanism is:

$\mathrm{H}_{2} \mathrm{O}+\mathrm{CO}_{2} \rightarrow \mathrm{H}_{2} \mathrm{CO}_{3}$ and $\mathrm{CaCO}_{3}+\mathrm{H}_{2} \mathrm{CO}_{3} \rightarrow \mathrm{CaH}\left(\mathrm{CO}_{3}\right)_{2}$

Calcium and $\mathrm{Mg}$ are the major cause of scale formation in pipes, water radiators, and boilers and to the horrible 

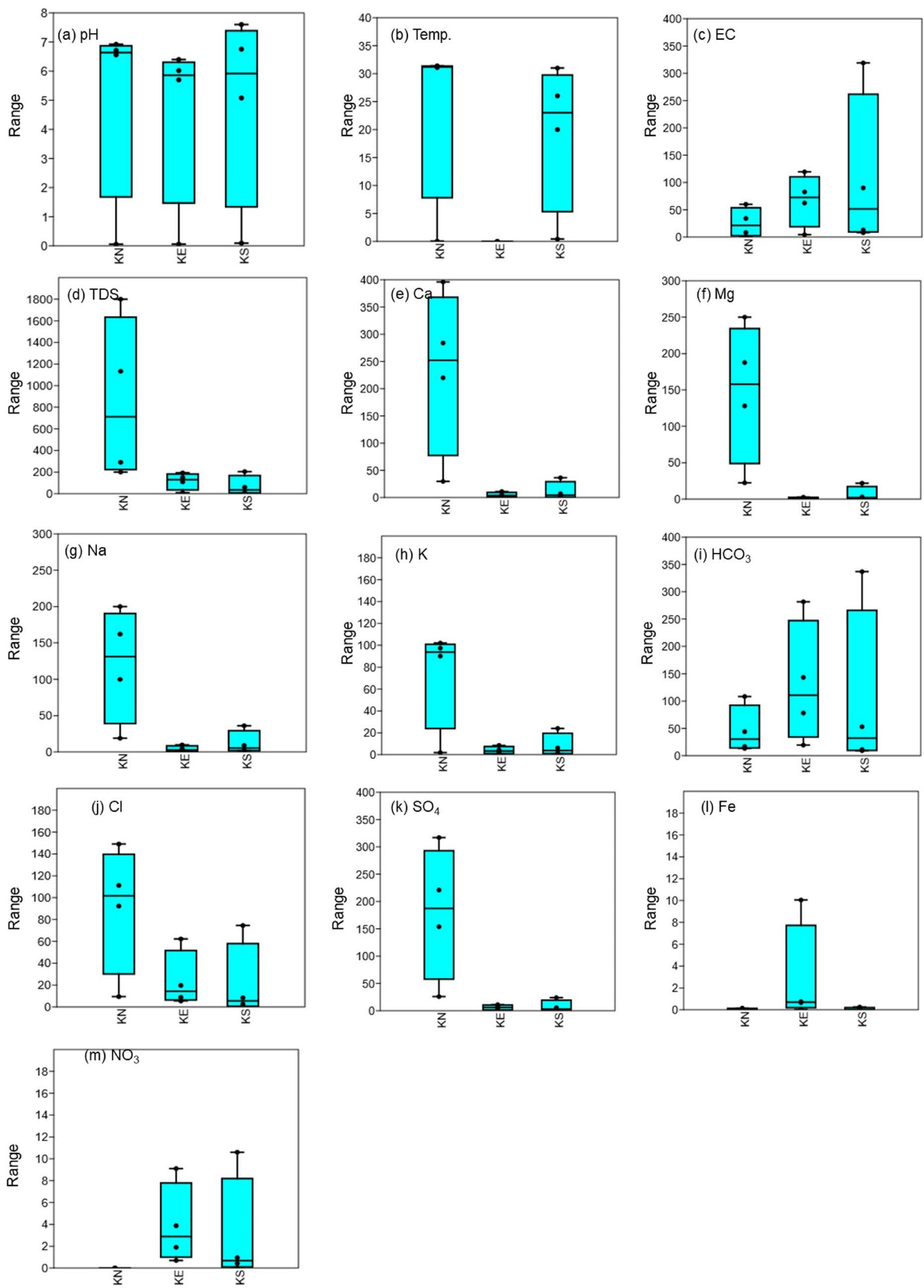

Fig. 5 Box and jitter plot of physicochemical elements of water quality in the Kaduna Basin. Note: All absorptions are in mg/l, except pH (unit), EC ( $\mu \mathrm{S} / \mathrm{cm})$ and temperature $\left({ }^{\circ} \mathrm{C}\right)$ 
curd within the sight of cleanser. The total reaction mechanism is:

$\mathrm{CaCO}_{3}(\mathrm{~s})+\mathrm{CO}_{2}(\mathrm{~g})+2 \mathrm{H}_{2} \mathrm{O}(\mathrm{I}) \rightarrow \mathrm{Ca}^{2+}(\mathrm{aq})+2 \mathrm{HCO}_{3}^{-}(\mathrm{aq})$

Sulfate concentrations are below the WHO guidelines as indicated in Table 4. Sulfide mineral oxidation is the primary source of $\mathrm{SO}_{4}$ in groundwater. Equally, sulfate can originate from calcium sulfate, sodium sulfate, and magnesium sulfate minerals $[89,90]$. Conversely, sulfate ions originate from industrial effluents and shales $[89,90]$. Sulfate is found in all types of aquifers because $\mathrm{SO}_{4}$ is one of the major dissolved components of precipitation. Highlevel $\mathrm{SO}_{4}$ in aquifers tends to be correlated with the emetic effect, chiefly if combined with $\mathrm{Mg}$ or $\mathrm{Na}[91,92]$.

\subsection{Groundwater evolution}

\subsubsection{Chadha diagram}

Groundwater classification based on the Chadha diagram (Fig. 6) showed that $11.54 \%(n=6)$ fall in field 4 representing $\mathrm{Na}-\mathrm{HCO}_{3}$ water type. Groundwater samples in field 4 are derived from the Kudenda-Nassarawa area. $\mathrm{Na}-\mathrm{Cl}$ water type occurred at one location representing $1.92 \%$. The location is in Kaduna South. The remaining locations $(n=45 ; 86.53 \%)$ fall in field 2 , indicating a Ca-Mg-Cl water type. Water samples in this field are comprised of the locations from Kakuri and its Environs $(n=15)$ and Kaduna South $(n=30)$. Results concur with the previous classifications of groundwater in the Kaduna Basin [12, 43, 93] and elsewhere in Nigeria's Basement Complex areas [94-97].

\subsubsection{Gibbs diagram}

The processes influencing the hydrogeochemistry of aquifers can also be revealed by Gibbs plot. It helps explains visibly, the pattern of groundwater sources producing a rebound-shaped cloud on a graph. Groundwater is not in a state of equilibrium with aquifer rock mineral, consequent of their mingling with recharged waters with distinct transport periods and often having higher $\mathrm{Ca}$ and $\mathrm{HCO}_{3}$ concentrations when compared with $\mathrm{Cl}$ and $\mathrm{Na}$ [64]. The hydrochemistry of aquifers in the study area is controlled by rock weathering, as depicted in Fig. 7. This symbolizes the inverse end member to precipitation sequence. It consisted of freshwaters drawing their main source of liquefied components from the rock minerals and soils from their basins. The compendium is classified as a rock weathering process as portrayed in Fig. 7. Results are concurrent with multivariate analysis.

\subsection{Suitability for drinking}

Table 5 presents groundwater classification based on nitrate $\left(\mathrm{NO}_{3}\right)$, chloride $(\mathrm{Cl})$, total hardness $(\mathrm{TH})$, electrical conductivity (EC), and total dissolved solids (TDS). Kudenda-Nassarawa area had TH above 300 mg/l, indicating very hard water. The TH values were less than $75 \mathrm{mg} / \mathrm{l}$ in Kakuri and its Environs, indicating soft water. Likewise, 93.55\% of sampling locations in Kaduna South had TH values less than $75 \mathrm{mg} / \mathrm{l}$ (soft water), 3.23\% (moderately hard water), and $3.23 \%$ (hard water). Hardness is influenced by several factors including soil/rock composition, the evolution of groundwater chemistry, and outflow from adjoining aquifers. Possible human controls on TH comprised

Table 4 Statistical summary of hydrochemical data derived from the literature

\begin{tabular}{|c|c|c|c|c|c|c|c|c|c|c|c|c|c|}
\hline \multirow[t]{2}{*}{ Parameter } & \multicolumn{4}{|c|}{ Kaduna South $(n=31)$} & \multicolumn{4}{|c|}{ Kakuri and Its Environs $(n=15)$} & \multicolumn{4}{|c|}{ Kudenda-Nassarawa area $(n=8)$} & \multirow[t]{2}{*}{ WHO (2011) } \\
\hline & Min & Max & Mean & SE & Min & Max & Mean & SE & Min & Max & Mean & SE & \\
\hline $\mathrm{pH}$ & 5.0 & 7.60 & 6.75 & 0.09 & 5.70 & 6.40 & 6.02 & 0.06 & 6.56 & 6.92 & 6.71 & 0.05 & $6.6-8.5$ \\
\hline Temp & 20.00 & 31.00 & 26.03 & 0.42 & ND & ND & ND & ND & 31.10 & 31.40 & 31.28 & 0.05 & Ambient \\
\hline EC & 8.00 & 319.00 & 90.09 & 12.99 & 62.37 & 119.43 & 82.74 & 4.25 & 0.47 & 60.00 & 34.08 & 8.27 & 1000 \\
\hline TDS & 5.12 & 204.00 & 59.60 & 8.98 & 109.60 & 192.90 & 149.51 & 9.02 & 200.00 & 1800.00 & 1133.33 & 290.59 & 500 \\
\hline $\mathrm{Ca}$ & 0.24 & 36.30 & 7.17 & 1.45 & 2.40 & 11.00 & 4.91 & 0.79 & 220.00 & 396.00 & 284.00 & 29.72 & 75 \\
\hline $\mathrm{Mg}$ & 0.22 & 21.89 & 3.06 & 0.85 & 0.50 & 2.60 & 1.43 & 0.22 & 128.00 & 250.00 & 187.67 & 22.39 & 125 \\
\hline $\mathrm{Na}$ & 1.61 & 36.09 & 8.91 & 1.62 & 0.70 & 9.70 & 4.40 & 0.87 & 100.00 & 200.00 & 162.00 & 18.90 & 200 \\
\hline $\mathrm{K}$ & 1.44 & 24.00 & 6.07 & 0.80 & 2.20 & 8.40 & 4.35 & 0.51 & 90.00 & 102.00 & 97.33 & 1.84 & 12 \\
\hline $\mathrm{Fe}$ & 0.00 & 0.25 & 0.04 & 0.01 & 0.03 & 10.05 & 0.74 & 0.66 & 0.02 & 0.15 & 0.09 & 0.02 & 2 \\
\hline $\mathrm{HCO}_{3}$ & 9.15 & 336.79 & 53.01 & 11.29 & 78.20 & 281.50 & 143.51 & 19.41 & 16.80 & 108.40 & 44.07 & 13.25 & 250 \\
\hline $\mathrm{Cl}$ & 0.00 & 74.50 & 8.37 & 2.63 & 8.80 & 62.20 & 19.65 & 5.47 & 92.30 & 149.10 & 111.13 & 9.45 & 250 \\
\hline $\mathrm{SO}_{4}$ & 0.00 & 23.90 & 5.46 & 1.01 & 3.90 & 11.20 & 8.23 & 0.63 & 153.70 & 316.90 & 220.87 & 26.00 & 250 \\
\hline $\mathrm{NO}_{3}$ & 0.00 & 10.60 & 0.95 & 0.42 & 1.90 & 9.10 & 3.87 & 0.70 & ND & ND & ND & ND & 50 \\
\hline
\end{tabular}

$N D$ no data (i.e., no $\mathrm{NO}_{3}$ measurements from Kudenda-Nassarawa area) 

groundwater classification in Kaduna Basin
Fig. 6 Chadha plot showing

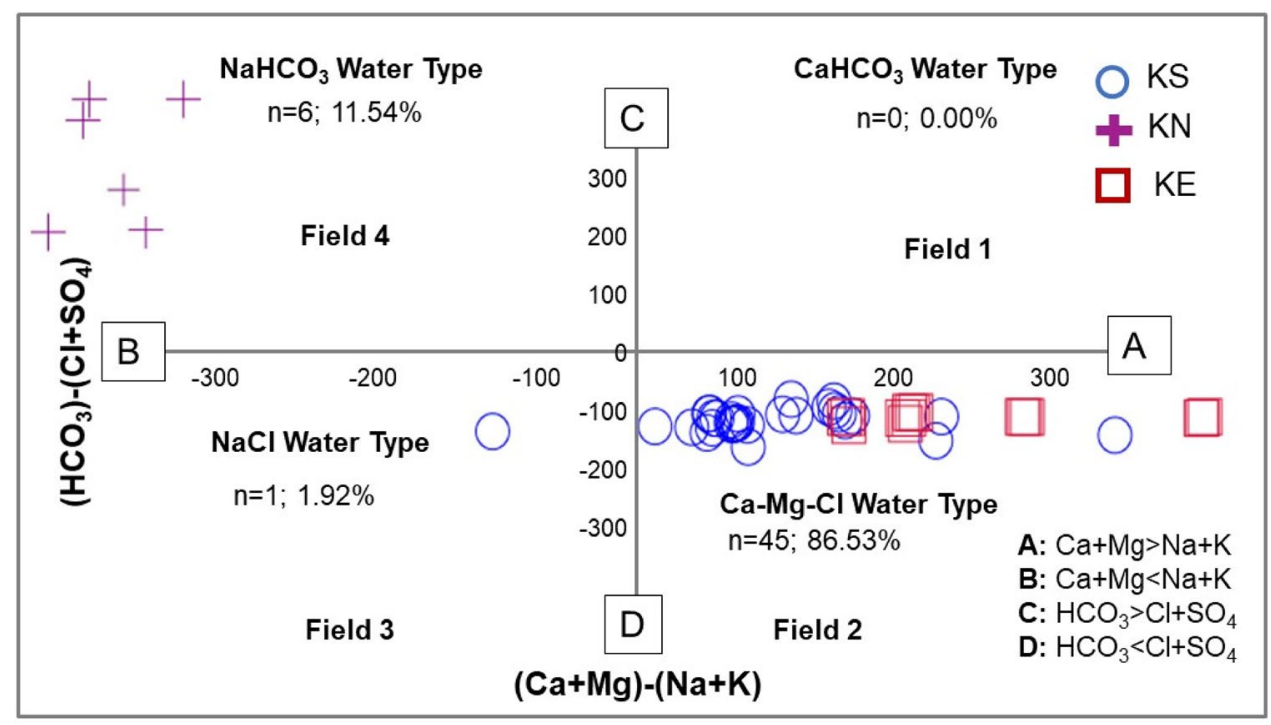

Fig. 7 A plot of ratio weight of TDS vs. $\mathrm{Na}+\mathrm{K} /(\mathrm{Na}+\mathrm{K}+\mathrm{Ca})$ and $\mathrm{Cl} /\left(\mathrm{Cl}+\mathrm{HCO}_{3}\right)$ for anions and cations. KN Kudenda-Nassarawa, KE Kakuri and Environs, KS Kaduna South

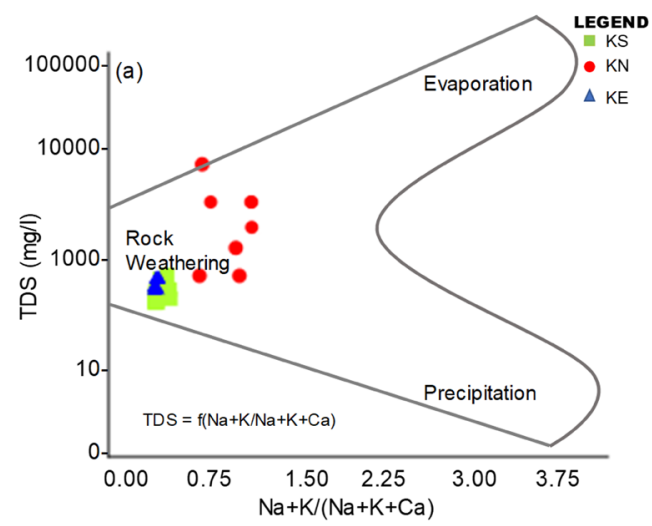

of flow from irrigation return and intrusion of saltwater induced by pumping [83].

The TDS level is generally low in the study area. TDS less than $500 \mathrm{mg} / \mathrm{l}$ denote excellent water. Kaduna South and Kakuri and its Environs had TDS less than 500 mg/l [6, 24, $62,98,99]$. In the Kudenda-Nassarawa area, $33.33 \%$ fall in excellent class, $16.67 \%$ are suitable (500-1000 mg/l TDS) and $33.33 \%$ are acceptable (1000-3000 mg/ITDS). The significance of TDS is that high ingestion may be connected to the strength of the joints, gallstones, kidney stones, inurement, or blockage of veins [100]. Based on chloride, $100 \%$ of water sources in the Kudenda-Nassarawa area are in the brackish salt class. Similarly, $80 \%$ are brackish and $20 \%$ are brackish salt in Kakuri and its Environs. In Kaduna South, the composition of groundwater varied from very fresh to brackish salt (Table 5). Chloride (Cl) is important to humans as it plays a significant role in the structure of the cell. Littoral aquifers can have high $\mathrm{Cl}$ level consequent of seawater invasion [101, 102]. At concentrations above $250 \mathrm{mg} / \mathrm{l}$, water taste can be influenced $[62,103]$.
Nitrate pollution is generally low. In Kakuri and its Environs, $80 \%$ of groundwater had $\mathrm{NO}_{3}$ concentrations less than $5 \mathrm{mg} / \mathrm{l}$. Water in this category is acceptable for drinking. Twenty percent (20\%) had $\mathrm{NO}_{3}$ concentration ranging from 5-30 mg/l. In Kaduna South, 93.55\% of groundwater had $\mathrm{NO}_{3}$ level of less than $5 \mathrm{mg} / \mathrm{l}$. The implication of high $\mathrm{NO}_{3}$ in drinking water is its harmful effects on children (blue baby syndrome). Nitrate in aquifers is derived from many sources such as soil organic matter, urban runoff, landfill, septic tanks, municipal sewage, and animal wastes [103]. Thus, it is expected that current contaminating activities will continuously impact the nitrate levels for many decades to come. If the groundwater abstraction is high, $\mathrm{NO}_{3}$ transport can be accelerated within the zone of saturation (Fig. 8). Therefore, a higher $\mathrm{NO}_{3}$ level in groundwater is a sign of previous anthropogenic pollution. 
Table 5 Water classification based on physicochemical parameters

\begin{tabular}{|c|c|c|c|c|c|c|c|}
\hline \multirow[t]{2}{*}{ Range } & \multirow[t]{2}{*}{ Classification } & \multicolumn{2}{|c|}{ Kudenda-Nassarawa } & \multicolumn{2}{|c|}{ Kakuri and its Environs } & \multicolumn{2}{|l|}{ Kaduna South } \\
\hline & & No. of samples & $\%$ of samples & No. of samples & $\%$ of samples & No. of samples & $\%$ of samples \\
\hline \multicolumn{8}{|l|}{ Hardness (mg/l) } \\
\hline Less than 75 & Soft & 0 & 0 & 15 & 100 & 29 & 93.55 \\
\hline $75-150$ & Moderately hard & 0 & 0 & 0 & 0 & 1 & 3.23 \\
\hline $150-300$ & Hard & 0 & 0 & 0 & 0 & 1 & 3.23 \\
\hline Above 300 & Very hard & 6 & 100 & 0 & 0 & 0 & 0 \\
\hline \multicolumn{8}{|l|}{ TDS (mg/l) } \\
\hline Less than 500 & Excellent & 2 & 33.33 & 15 & 100 & 31 & 100 \\
\hline $500-1000$ & Acceptable & 1 & 16.67 & 0 & 0 & 0 & 0 \\
\hline $1000-3000$ & Suitable & 2 & 33.33 & 0 & 0 & 0 & 0 \\
\hline Above 3000 & Unsuitable & 0 & 0 & 0 & 0 & 0 & 0 \\
\hline \multicolumn{8}{|l|}{$\mathrm{EC}(\mu \mathrm{S} / \mathrm{cm})$} \\
\hline Less than 250 & Excellent & 6 & 100 & 15 & 100 & 31 & 100 \\
\hline $250-750$ & Good & 0 & 0 & 0 & 0 & 0 & 0 \\
\hline $750-2000$ & Permissible & 0 & 0 & 0 & 0 & 0 & 0 \\
\hline $2000-3000$ & Doubtful & 0 & 0 & 0 & 0 & 0 & 0 \\
\hline Above 3000 & Unsuitable & 0 & 0 & 0 & 0 & 0 & 0 \\
\hline \multicolumn{8}{|l|}{ Chloride (mg/l) } \\
\hline Less than 0.14 & Awfully fresh & 0 & 0 & 0 & 0 & 4 & 12.90 \\
\hline $0.14-0.85$ & Very fresh & 0 & 0 & 0 & 0 & 1 & 3.23 \\
\hline $0.85-4.23$ & Fresh & 0 & 0 & 0 & 0 & 14 & 45.16 \\
\hline $4.23-8.46$ & Fresh brackish & 0 & 0 & 0 & 0 & 5 & 16.13 \\
\hline $8.46-28.21$ & Brackish & 0 & 0 & 12 & 80 & 6 & 19.35 \\
\hline $28.21-546.13$ & Brackish salt & 6 & 100 & 3 & 20 & 1 & 3.23 \\
\hline Above 564.13 & Hypersaline & 0 & 0 & 0 & 0 & 0 & 0 \\
\hline \multicolumn{8}{|l|}{ Nitrate (mg/l) } \\
\hline Less than 5 & Acceptable & ND & 0 & 12 & 80 & 29 & 93.55 \\
\hline $5-30$ & Moderate & ND & 0 & 3 & 20 & 2 & 6.45 \\
\hline Above 30 & Severe & ND & 0 & 0 & 0 & 0 & 0 \\
\hline
\end{tabular}

\subsection{Water quality index}

The water quality index (WQI) of Kaduna Basin (mean \pm standard error) was 8.387 \pm 1.088 in Kudenda-Nassarawa area, $2.062 \pm 0.376$ in Kakuri and its Environs, and $1.204 \pm 0.109$ in Kaduna South, respectively (Fig. 9). The computed WQI revealed that the overall WQI was 13.46 in the Kudenda-Nassarawa area, 7.64 in Kakuri and its Environs, and 10.26 in Kaduna South. The study area holds groundwater of excellent quality based on WQI (Table 6). Calcium, potassium, and TDS are the primary elements controlling water quality in the Kudenda-Nassarawa area. Iron is the major element influencing water quality in Kakuri and its Environs. In contrast, $\mathrm{pH}$ was the major element controlling water quality in Kaduna South. The $\mathrm{pH}$ values indicated an alkaline condition. High $\mathrm{pH}$ in aquifers means that the water can buffer acidic solution having elevated levels of hydrogen ions. The high dissolution of carbon-based minerals is the primary source of high $\mathrm{pH}$ in aquifers. Alkaline water tends to be hard. The major mineral compound triggering high $\mathrm{pH}$ (or alkalinity) in aquifers is calcium carbonate. It is chiefly derived from mineral rocks including limestone, dolomite, and calcite [105-109].

\subsection{Groundwater classification based on LSI and RSI}

The Langelier Saturation Index (LSI) (mean \pm standard error) was $-2.71 \pm 0.18$ and ranged from -5.30 to -1.00 in Kaduna South, $-2.03 \pm 0.27$ and ranged from -5.30 to 0.18 , in the Kudenda-Nassarawa. The LSI was $-3.00 \pm 0.39$ and ranged from -5.30 to 0.27 in Kakuri and its environs (Table 7; Fig. 10a). Table 7 presents the groundwater classification based on LSI. In Kaduna South, $74.19 \%$ of groundwater samples fall in very aggressive class, and $25.81 \%$ fall in moderately aggressive class. In the Kudenda-Nassarawa area, $16.67 \%$ are very aggressive, $66.67 \%$ are moderately aggressive and $16.67 \%$ are non-aggressive. Very aggressive 


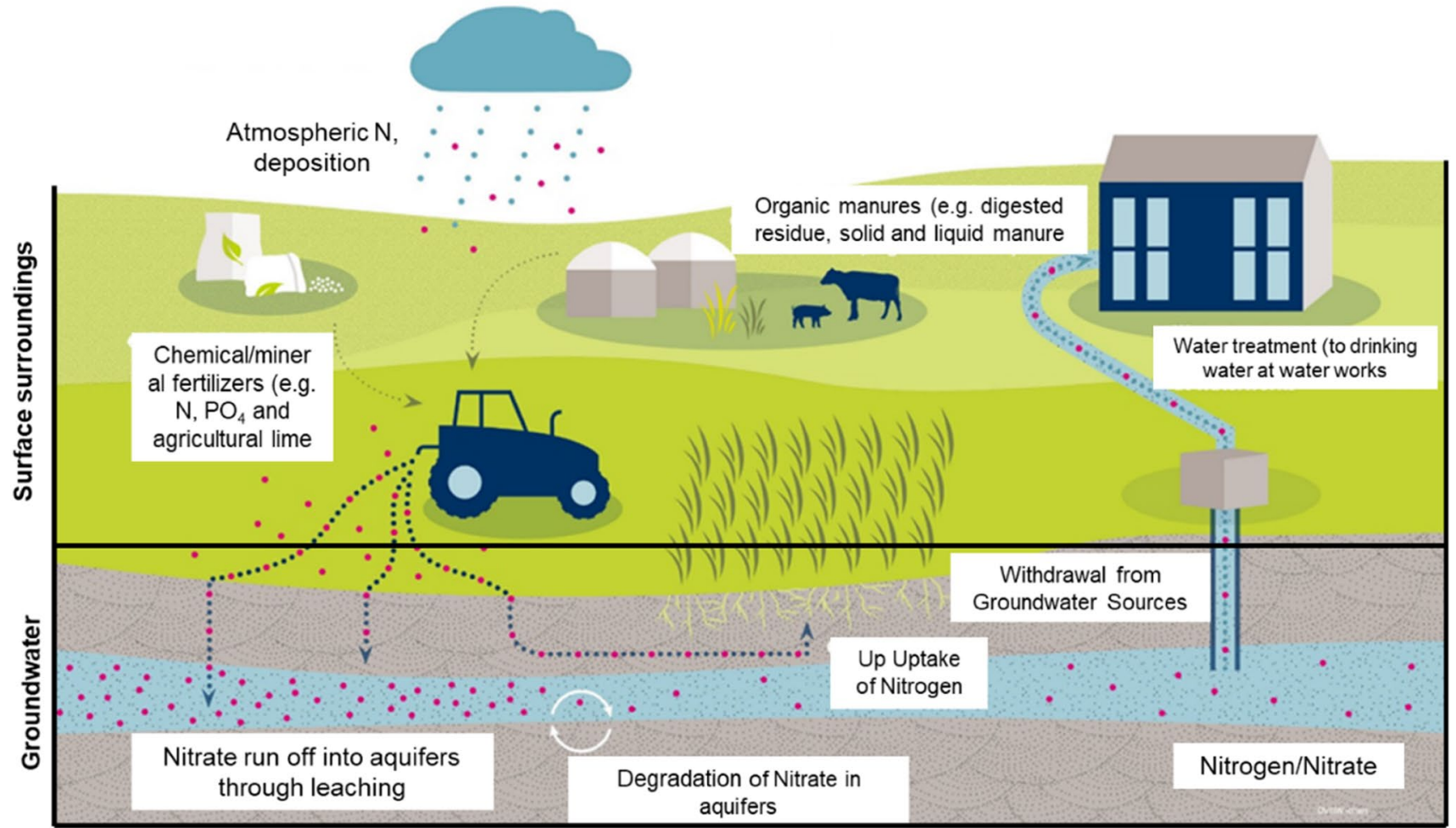

Fig. 8 Conceptual model of $\mathrm{NO}_{3}$ occurrence in groundwater. After DVGW [104]

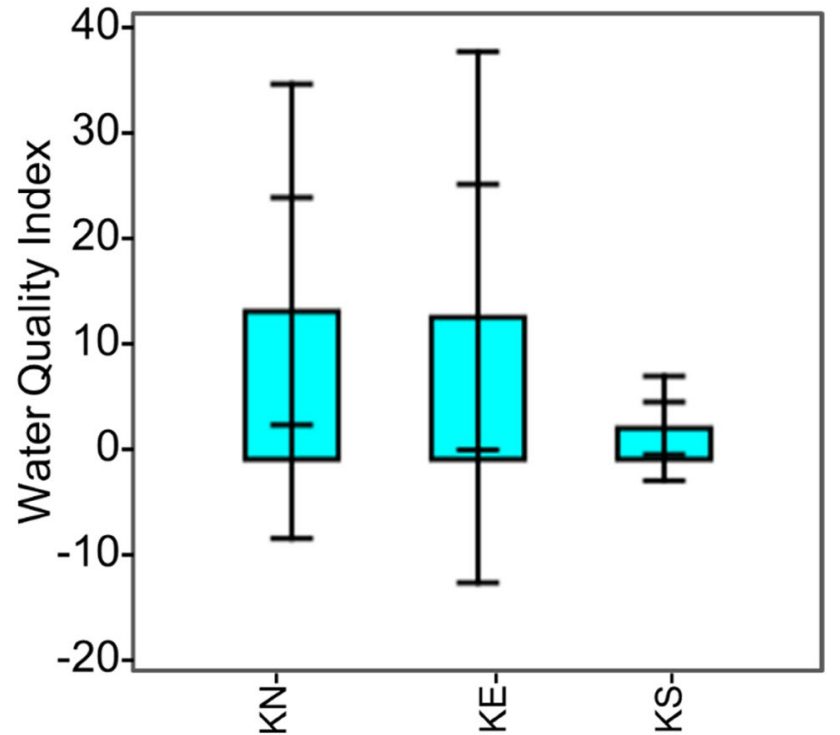

Fig. 9 Box and jitter plot showing calculated water quality index

water occurred in the Kakuri and its Environs. Non-aggressive water is ideal for industrial uses [10,52].

Table 8 and Fig. 10b summarize the groundwater classification based on the Ryznar Stability Index (RSI). The
Table 6 Groundwater classification based on WOI

\begin{tabular}{lllll}
\hline Range & Classification & $\begin{array}{l}\text { Kudenda- } \\
\text { Nassarawa }\end{array}$ & $\begin{array}{l}\text { Kakuri and } \\
\text { its Environs }\end{array}$ & $\begin{array}{l}\text { Kaduna } \\
\text { South }\end{array}$ \\
\hline Less than 50 & Excellent & 13.4628 & 7.64 & 10.26 \\
$50-100$ & Good & 0 & 0 & 0 \\
$100-200$ & Poor & 0 & 0 & 0 \\
$200-300$ & Very poor & 0 & 0 & 0 \\
\hline
\end{tabular}

RSI values were above 8.5 in Kaduna South and Kakuri and its Environs, indicative of extremely aggressive water. Similarly, 83.33\% of RSI values in Kudenda-Nassarawa are between 6.2 and 8.5, indicative of aggressive water. However, $16.67 \%$ is acceptable for industrial use. Saturation index is essential for rating the extent of precipitation by water running through pipes or the extent of the dissolution of calcium carbonate. Groundwater in Kaduna Basin is unsuitable for industrial use.

\subsection{Statistical application}

\subsubsection{Factor analysis}

Factor analysis (FA) is a widely applied statistical method in hydrogeochemical analysis. It is used to classify 
Table 7 Groundwater classification based on Langelier Saturation Index

\begin{tabular}{|c|c|c|c|c|c|c|c|}
\hline \multirow[t]{2}{*}{ Range } & \multicolumn{2}{|c|}{ Kaduna South } & \multicolumn{2}{|c|}{ Kudenda-Nassarawa } & \multicolumn{2}{|c|}{$\begin{array}{l}\text { Kakuri and its Envi- } \\
\text { rons }\end{array}$} & \multirow[t]{2}{*}{ Classification } \\
\hline & $\begin{array}{l}\text { No. of } \\
\text { sam- } \\
\text { ples }\end{array}$ & $\%$ of samples & $\begin{array}{l}\text { No. of } \\
\text { water } \\
\text { samples }\end{array}$ & $\begin{array}{l}\% \text { of } \\
\text { water } \\
\text { samples }\end{array}$ & $\begin{array}{l}\text { No. of } \\
\text { water } \\
\text { samples }\end{array}$ & $\begin{array}{l}\% \text { of } \\
\text { water } \\
\text { samples }\end{array}$ & \\
\hline Less than -2.0 & 23 & 74.19 & 1 & 16.67 & 15 & 100.00 & Very aggressive \\
\hline-2.0 to 0.0 & 8 & 25.81 & 4 & 66.67 & 0 & 0.00 & Moderate \\
\hline Above 0.0 & 0 & 0.00 & 1 & 16.67 & 0 & 0.00 & Non-aggressive \\
\hline
\end{tabular}

Fig. 10 Box and jitter plot: a Langelier Saturation Index and b Ryznar Stability Index
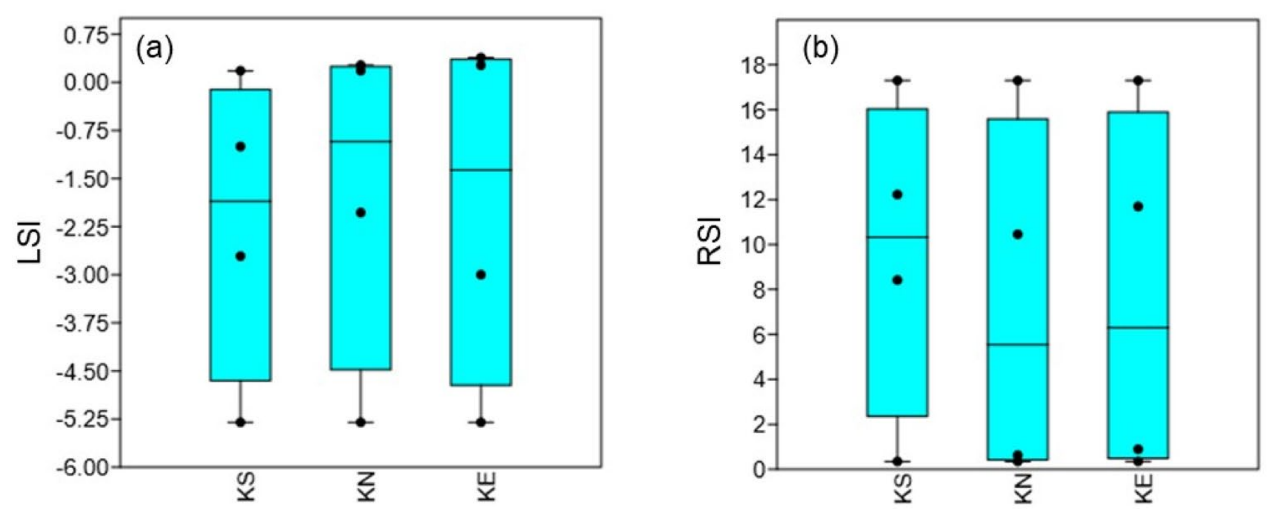

Table 8 Groundwater classification based on the Ryznar Stability Index

\begin{tabular}{|c|c|c|c|c|c|c|c|}
\hline \multirow[t]{2}{*}{ Range } & \multicolumn{2}{|c|}{ Kaduna South } & \multicolumn{2}{|c|}{ Kudenda-Nassarawa } & \multicolumn{2}{|c|}{ Kakuri and its Environs } & \multirow[t]{2}{*}{ Classification } \\
\hline & $\begin{array}{l}\text { No. of water } \\
\text { samples }\end{array}$ & $\begin{array}{l}\% \text { of water } \\
\text { samples }\end{array}$ & $\begin{array}{l}\text { No. of water } \\
\text { samples }\end{array}$ & $\begin{array}{l}\% \text { of water } \\
\text { samples }\end{array}$ & $\begin{array}{l}\text { No. of water } \\
\text { samples }\end{array}$ & $\begin{array}{l}\% \text { of water } \\
\text { samples }\end{array}$ & \\
\hline Below 5.5 & 0.00 & 0.00 & 0.00 & 0.00 & 0.00 & 0.00 & Heavy scale \\
\hline $5.5-6.2$ & 0.00 & 0.00 & 0.00 & 0.00 & 0.00 & 0.00 & Moderate scale \\
\hline $6.2-6.8$ & 0.00 & 0.00 & 1.00 & 16.67 & 0.00 & 0.00 & Acceptable \\
\hline $6.8-8.5$ & 0.00 & 0.00 & 5.00 & 83.33 & 0.00 & 0.00 & Aggressive water \\
\hline Above 8.5 & 31.00 & 100.00 & 0.00 & 0.00 & 15.00 & 100.00 & Extremely aggressive \\
\hline
\end{tabular}

hydrogeochemical data and relates it to the origin of ions in aquifers. Factor analysis was conducted on 13 subsets of parameters (Table 9). Factor 1 had high positive correlations on $\mathrm{pH}, \mathrm{EC}$, TDS, temperature $\mathrm{HCO}_{3}, \mathrm{SO}_{4}$, and $\mathrm{K}$ in Kudenda-Nassarawa (KN), $\mathrm{HCO}_{3}, \mathrm{NO}_{3}, \mathrm{Na}, \mathrm{Ca}$, and $\mathrm{K}$ in Kakuri and its Environs (KE), TDS, EC, and $\mathrm{Cl}$ in Kaduna South (KS). Factor 1 correlated with the rock weathering process. However, a high positive correlation on $\mathrm{NO}_{3}$ is suggestive of anthropogenic contributions because $\mathrm{NO}_{3}$ is continuously added from the $\mathrm{N}$-rich fertilizers, oxidation of ammonia, and macrobiotic waste. Chloride is gradually increased in the environment by human activities [110-112]. Factor 2 had positive correlations on $\mathrm{Na}, \mathrm{Mg}$ $\mathrm{Fe}$, and $\mathrm{Ca}$ in $\mathrm{KN}$; $\mathrm{EC}$, TDS, and $\mathrm{SO}_{4}$, in $\mathrm{KE}$; and $\mathrm{HCO}_{3}, \mathrm{Mg}$, and $\mathrm{Ca}$ in $\mathrm{KS}$. Factor 2 is exclusively correlated with rock weathering.
Factor 3 had high positive loading on $\mathrm{Cl}$ and $\mathrm{Mg}$ in $\mathrm{KN}$; $\mathrm{Mg}$ in $\mathrm{KE}, \mathrm{SO}_{4}$, and $\mathrm{K}$ in $\mathrm{KS}$. Factor 3 can be correlated with rock weathering. Insignificant correlation on $\mathrm{Ca}$ and $\mathrm{Mg}$ in Factor 1 from $\mathrm{KN}$ is pleasing since $\mathrm{pH}$ regularly attains an opposite relationship with ions of carbonate source [62, 113]. Figure 11 demonstrates the biplot of the extracted factors. The three factors accounted for $83.539 \%$ of the total variance in $\mathrm{KN}, 86.653 \%$ in $\mathrm{KE}$, and $59.866 \%$ in $\mathrm{KS}$, respectively. These factors have the highest eigenvalues.

\subsubsection{Hierarchical clustering analysis}

The use of hierarchical clustering analysis (HCA) in hydrogeochemical analysis aids the classification of aquifers by separating hydrogeochemical data that acts contrarywise. Groundwater sources with comparable hydrogeochemical 
Table 9 Rotated (varimax) factor scores of hydrochemical data

\begin{tabular}{|c|c|c|c|c|c|c|c|c|c|}
\hline \multirow[t]{2}{*}{ Parameter } & \multicolumn{3}{|c|}{ Kudenda-Nassarawa } & \multicolumn{3}{|c|}{ Kakuri and Environs } & \multicolumn{3}{|c|}{ Kaduna South } \\
\hline & 1 & 2 & 3 & 1 & 2 & 3 & 1 & 2 & 3 \\
\hline $\mathrm{pH}$ & 0.892 & -0.19 & 0.286 & 0.42 & 0.77 & -0.093 & -0.143 & -0.171 & 0.275 \\
\hline Temp & 0.801 & 0.219 & 0.161 & ND & ND & ND & 0.345 & 0.167 & -0.124 \\
\hline $\mathrm{EC}$ & 0.912 & 0.221 & -0.299 & -0.116 & 0.976 & -0.014 & 0.914 & 0.111 & -0.254 \\
\hline TDS & 0.719 & 0.335 & 0.08 & 0.28 & 0.841 & 0.325 & 0.876 & 0.127 & -0.304 \\
\hline $\mathrm{Ca}$ & 0.07 & 0.926 & -0.079 & 0.787 & 0.579 & 0.178 & -0.096 & 0.817 & 0.041 \\
\hline $\mathrm{Mg}$ & 0.071 & 0.66 & 0.674 & 0.503 & 0.066 & 0.702 & 0.407 & 0.808 & 0.192 \\
\hline $\mathrm{Na}$ & -0.135 & 0.901 & 0.391 & 0.718 & 0.581 & -0.19 & 0.503 & 0.757 & 0.026 \\
\hline K & 0.787 & 0.297 & -0.416 & 0.737 & -0.22 & -0.417 & 0.116 & 0.01 & 0.726 \\
\hline $\mathrm{Fe}$ & 0.212 & 0.861 & -0.055 & 0.077 & -0.03 & -0.816 & 0.132 & -0.039 & -0.469 \\
\hline $\mathrm{HCO}_{3}$ & 0.78 & -0.064 & 0.286 & 0.747 & 0.566 & 0.327 & -0.011 & 0.963 & -0.051 \\
\hline $\mathrm{Cl}$ & 0.268 & 0.06 & 0.895 & 0.907 & 0.339 & 0.236 & 0.788 & -0.053 & 0.308 \\
\hline $\mathrm{SO}_{4}$ & 0.839 & -0.218 & 0.217 & 0.318 & 0.794 & 0.111 & 0.581 & 0.026 & 0.682 \\
\hline $\mathrm{NO}_{3}$ & ND & ND & ND & 0.949 & 0.223 & 0.155 & 0.103 & -0.087 & -0.312 \\
\hline$\%$ of variance & 43.287 & 25.721 & 14.53 & 57.741 & 16.362 & 12.55 & 30.304 & 16.633 & 12.929 \\
\hline Eigenvalue & 5.194 & 3.087 & 1.744 & 6.929 & 1.963 & 1.506 & 3.939 & 2.162 & 1.681 \\
\hline Cumulative \% & 43.287 & 69.008 & 83.539 & 57.741 & 74.103 & 86.653 & 30.304 & 46.937 & 59.866 \\
\hline
\end{tabular}

Values in bold indicated a significant correlation ( $\geq 0.65$ ). ND no data (i.e., data not observed)
Fig. 11 Factor analysis (biplot) showing the variability of hydrogeochemical elements a Kaduna South, b KudendaNassarawa, and c Kakuri and its Environs
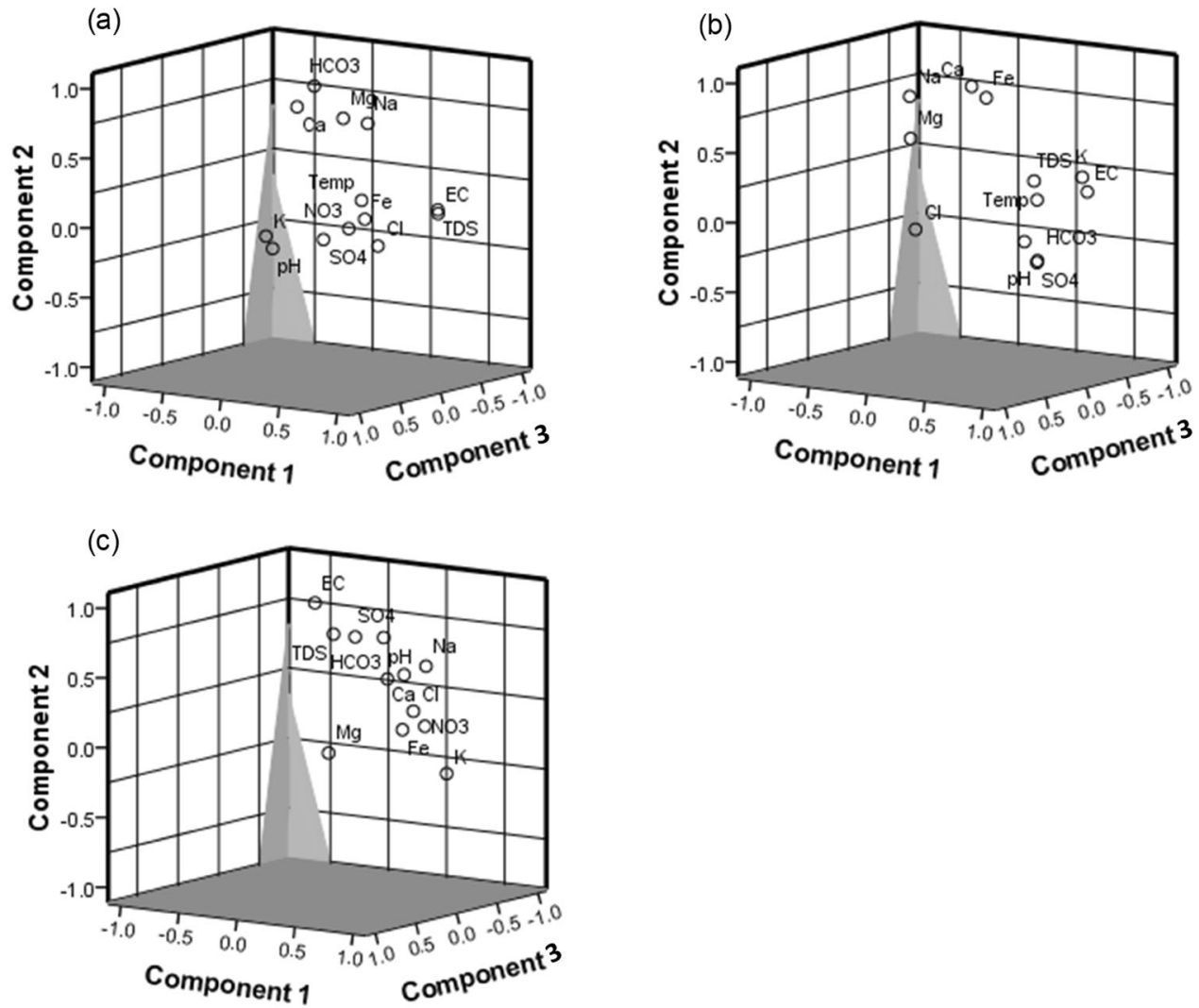

characteristics tend to produce a discrete cluster. The graphical image of the grouping procedure is given as a dendrogram (Fig. 12). Cluster 1 is consisting of wells in the Kudenda-Nassarawa area and is having analogous concentrations of temperature and $\mathrm{pH}$. So, it can be correlated with physical/external control (i.e., extreme temperatures), with its consequential effect on chemical reactions within aquifers. Inconsistency of temperature $\left(5-10^{\circ} \mathrm{C}\right)$ in 
Fig. 12 Hydrogeochemical characteristics of groundwater based on hierarchical cluster analysis

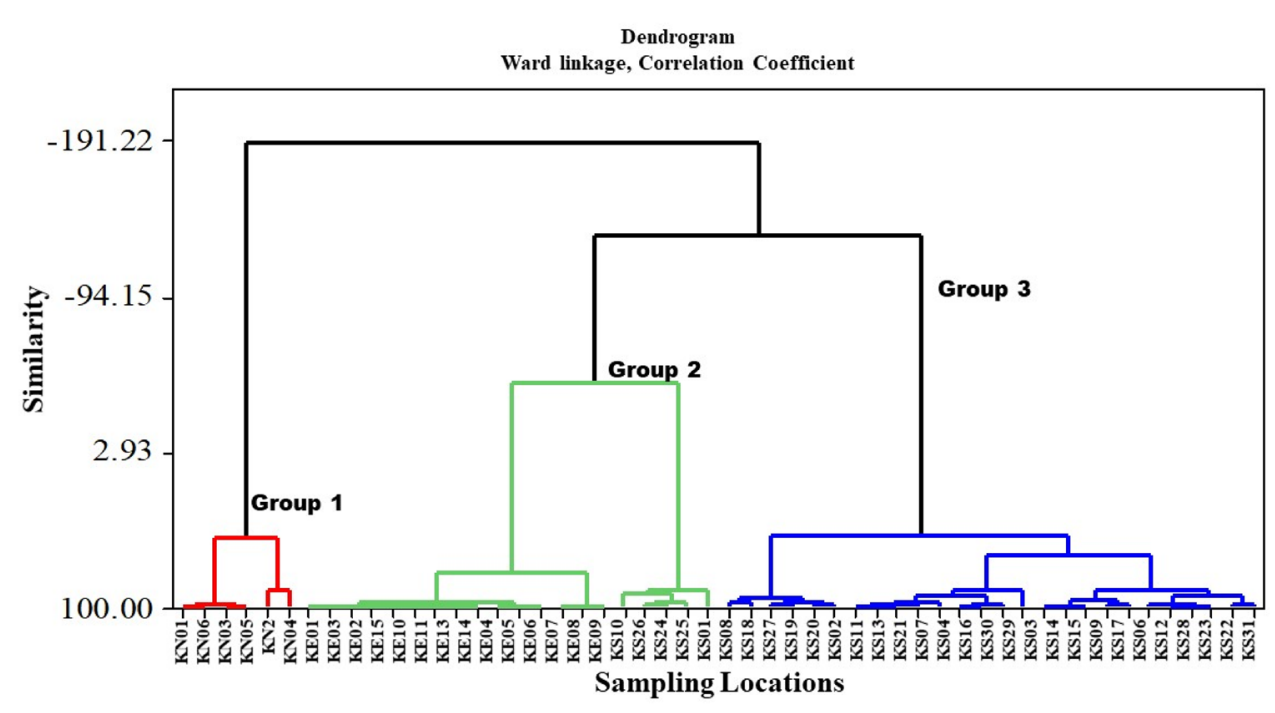

groundwater influences TDS concentration, which eventually disturbs complexation, ion exchange, the solubility of gasses, redox reaction, sorption process, speciation process, and $\mathrm{pH}$ level $[62,114-118]$. Cluster 2 comprises of wells in Kakuri and Environs and some wells (KS10, KS26, $\mathrm{KS} 24, \mathrm{KS} 25$ and KS01). It is characterized by analogous concentrations of $\mathrm{SO}_{4}, \mathrm{Cl}, \mathrm{Mg}, \mathrm{Ca}, \mathrm{K}, \mathrm{Na}$, and TDS. Cluster 3 is comprised of wells in Kaduna South and are having parallel concentrations of $\mathrm{NO}_{3}, \mathrm{HCO}_{3}, \mathrm{Fe}$, and EC. Cluster 2 and 3 can be correlated with the rock weathering. However, $\mathrm{NO}_{3}$ and $\mathrm{SO}_{4}$ concentrations in groundwater are increasing consequent of agriculture and household chemicals $[62,116-120]$.

\subsubsection{Generalized regression model}

A general regression model was generated using MINITAB (mbt 16) statistical software, to identify the major hydrochemical parameter(s) influencing the hydrochemistry of aquifers in the Kaduna Basin. Electrical conductivity (EC) was choosing to be a response variable, while the remaining 12 parameters were predictors. Although EC cannot be associated with any specific chemical parameter; it is an excellent indicator of the overall ionic concentrations of water. It informs the range into which ionic concentrations are likely to fall. Consequently, it enables a water quality analyst to take suitable decisions relating to water usage. A significant relationship between $\mathrm{EC}$ and certain ions is an indicator of major ionic effect on the hydrochemistry of aquifers. The regression equation is thus: $\mathrm{EC}=123.553-11.2206 \mathrm{pH}-1.71577$ $\mathrm{Ca}-4.41477 \mathrm{Mg}+5.99857 \mathrm{Na}+0.929561 \mathrm{~K}-0.178372$ $\mathrm{HCO}_{3}+0.903213 \mathrm{Cl}-0.16986 \mathrm{SO}_{4}-3.40888 \mathrm{Fe}+0.162469$ TDS $+0.582821 \mathrm{NO}_{3}$.
The model as summarized in Table 10 showed that $\mathrm{Ca}$, $\mathrm{Mg}, \mathrm{Na}$, and TDS are the most important hydrochemical variables influencing EC levels. The residual plots are summarized in Fig. 13. It was used to verify the hypothesis that residuals are normally distributed. The normal probability plot of the residuals approximately follows a straight line (Fig. 13a). The overall $P$ value is $<0.001$. The observed relative normality in this analysis, confirmed the accuracy of the model used. The hydrochemical parameters with $P$ value $<0.005$ are considered significant. Calcium, Mg, Na, and TDS have $P$ value $<0.001$. These elements represented the most important parameters affecting the hydrochemical composition of aquifers in the study area. Further, the model output had clearly shown no significant anthropogenic inputs ( $P$ value $>0.005, \mathrm{NO}_{3} ; \mathrm{Cl}$ ) in the study area.

\section{Conclusion}

With increasing industrial activities and urbanization, more groundwater is harnessed. Kaduna Basin has a semiarid tropical climate. This coupled with changes in land use posed a threat to water quality. While human activities can alter the hydrochemistry of aquifers, understanding the natural processes influencing the hydrochemistry of aquifers is also important. Kaduna-Kano zone represents the most urbanized and industrialized section of northern Nigeria. Thus, the appraisal of subsurface water by rating its quality for domestic and industrial uses is important. The use of WQIs to classify groundwater has demonstrated the effectiveness of these techniques for rating the quality of groundwater aquifers. Results obtained from this review lead to the following remarks: 
Table 10 Summary of the general regression model

\begin{tabular}{|c|c|c|c|c|c|c|}
\hline \multicolumn{4}{|c|}{ Model summary } & \multirow{2}{*}{$\frac{S}{44.6605}$} & \multirow{2}{*}{$\frac{\mathrm{R}-\mathrm{Sq} \%}{55.33}$} & \multirow{2}{*}{$\begin{array}{l}\text { Rsq (Adj)\% } \\
43.05\end{array}$} \\
\hline & & & & & & \\
\hline \multicolumn{7}{|c|}{ Analysis of variance } \\
\hline Source & $D F$ & Seq SS & Adj SS & Adj MS & $F$ & $P$ \\
\hline Regression & 11 & 98,839 & $98,839.2$ & 8985.4 & 4.5049 & 0.000202 \\
\hline $\mathrm{pH}$ & 1 & 427 & 1459.5 & 1459.5 & 0.7318 & 0.397409 \\
\hline $\mathrm{Ca}$ & 1 & 13,985 & $22,274.1$ & $22,274.1$ & 11.1674 & 0.001814 \\
\hline $\mathrm{Mg}$ & 1 & 279 & $62,534.2$ & $62,534.2$ & 31.3523 & 0.000002 \\
\hline $\mathrm{Na}$ & 1 & 27,336 & $50,780.8$ & $50,780.8$ & 25.4596 & 0.00001 \\
\hline K & 1 & 6424 & 583 & 583 & 0.2923 & 0.59175 \\
\hline $\mathrm{HCO}_{3}$ & 1 & 87 & 5530.9 & 5530.9 & 2.773 & 0.103681 \\
\hline $\mathrm{Cl}$ & 1 & 5755 & 7195.8 & 7195.8 & 3.6077 & 0.06474 \\
\hline $\mathrm{SO}_{4}$ & 1 & 0 & 384.1 & 384.1 & 0.1926 & 0.663138 \\
\hline $\mathrm{Fe}$ & 1 & 445 & 1083.9 & 1083.9 & 0.5434 & 0.465324 \\
\hline TDS & 1 & 44,032 & $43,626.5$ & $43,626.5$ & 21.8727 & 0.000033 \\
\hline $\mathrm{NO}_{3}$ & 1 & 69 & 69.2 & 69.2 & 0.0347 & 0.85318 \\
\hline Error & 40 & 79,782 & $79,782.5$ & 1994.6 & & \\
\hline Total & 51 & 178,622 & & & & \\
\hline
\end{tabular}

Fig. 13 Summary of regression analysis

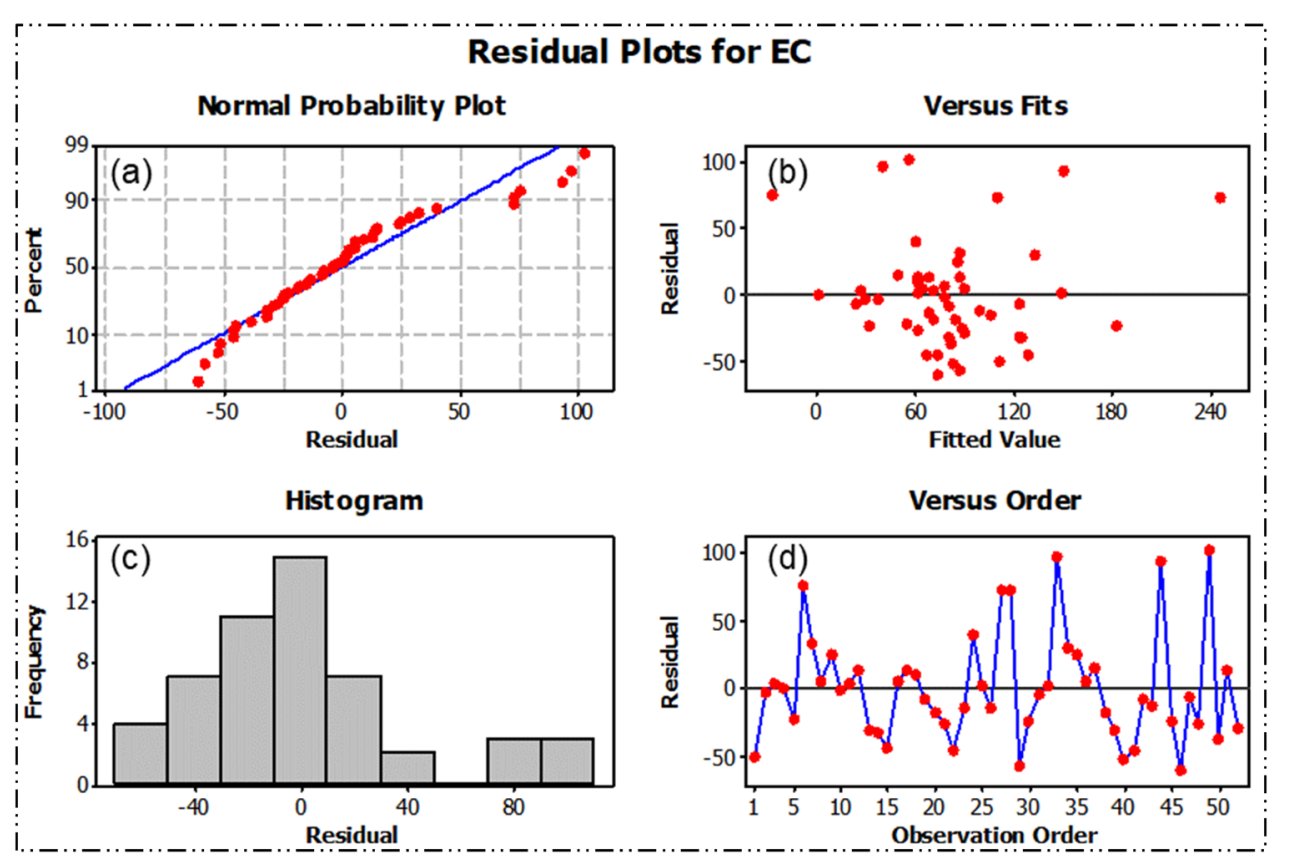

1. Mean concentration of TDS, $\mathrm{Ca}, \mathrm{Mg}$, and $\mathrm{K}$ is above WHO (2011) reference guidelines for drinking water in Kudenda-Nassarawa area;

2. Groundwater classification based on the Chadha diagram showed that the Kudenda-Nassarawa area had a $\mathrm{Na}-\mathrm{HCO}_{3}$ water type. $\mathrm{Na}-\mathrm{Mg}-\mathrm{Cl}$ water type occurred in Kaduna South and Kakuri and its Environs;
3. Groundwater sources in the Kudenda-Nassarawa area had TH above 300 mg/l, indicating very hard water. The $\mathrm{TH}$ values are less than 75 mg/l in Kakuri and its environs, indicating soft water;

4. Likewise, $93.55 \%$ of groundwater in Kaduna South had $\mathrm{TH}$ values less than $75 \mathrm{mg} / \mathrm{l}$, indicating soft water; 
5. The TDS level was less than $500 \mathrm{mg} / \mathrm{l}$ in Kaduna South and Kakuri and its Environs, indicative of excellent water for drinking;

6. Based on chloride, $100 \%$ of water sources in the Kudenda-Nassarawa area fell in brackish salt class;

7. Similarly, $80 \%$ are brackish and $20 \%$ are brackish salt in Kakuri and its Environs. Kaduna South had very fresh to brackish saltwater type;

8. Nitrate pollution is generally low. In Kakuri and its Environs, $80 \%$ of water samples have $\mathrm{NO}_{3}$ concentrations less than $5 \mathrm{mg} / \mathrm{l}$ and $20 \%$ had $\mathrm{NO}_{3}$ levels ranging from $5-30 \mathrm{mg} / \mathrm{l}$;

9. In Kaduna South, $93.55 \%$ of groundwater sources have $\mathrm{NO}_{3}$ level below $5 \mathrm{mg} /$;

10. The computed WQI revealed that the overall WQI was 13.46 in the Kudenda-Nassarawa area, 7.64 in Kakuri and its Environs, and 10.26 in Kaduna South;

11. Based on LSI and RSI, $16.67 \%$ was very aggressive, $66.67 \%$ was moderately aggressive and $16.67 \%$ was non-aggressive in the Kudenda-Nassarawa area. Very aggressive water occurred under Kakuri and its Environs;

12. Groundwater is primarily controlled by rock weathering as indicated by multivariate analysis and Gibb's model; and

13. Regression analysis revealed the hydrochemical parameters with $\mathrm{P}$-value $<0.005$ are $\mathrm{Ca}, \mathrm{Mg}, \mathrm{Na}$, and $\mathrm{NO}_{3}$. These elements represented the most significant elements controlling the hydrochemistry of aquifers in the Kaduna Basin.

Based on these revelations, it can be inferred that groundwater in Kaduna Basin is unsuitable for industrial use. It is undersaturated with $\mathrm{CaCO}_{3}$. Undersaturated water can take off existing $\mathrm{CaCO}_{3}$ protecting shells within equipment and pipelines. Classification of water using WQIs and saturation indices presented a userfriendly tool for rating sources of water supply. It helps to figure out the suitability of water for domestic and industrial uses. We hope that this review will stimulate other researchers to a similar method in an upcoming investigation on water quality.

Acknowledgements This study was sponsored by Universiti Teknologi Malaysia via GUP Tier 1 Vote Number Q.J130000.2522.20H53. Sincere thanks to all unmentioned contributors. Thanks also to anonymous reviewers for their constructive comments which have helped to improve the paper.

\section{Compliance with ethical standards}

Conflict of interest There is no conflicting interest associated with this review.

\section{References}

1. Damo R, Icka P (2013) Evaluation of water quality index for drinking water. Pol J Environ Stud 22(4):1045-1051

2. Paul AZ, Ken JH (1998) Analysis of British Columbia water quality index for watershed managers: a case study of two watersheds. Water Qual Res J Can 33(4):519-549

3. Gaska K et al (2018) A high-performance computing (HPC) based integrated multithreaded model predictive control (MPC) for water supply networks. Arch Civ Eng Environ 10(4):141-151

4. Ibrahim M (2019) Assessing groundwater quality for drinking purpose in Jordan: application of water quality index. J Ecol Eng 20(3):101-111

5. Pande CB et al (2019) Groundwater evaluation for drinking purposes using statistical index: study of Akola and Buldhana districts of Maharashtra, India. Environ Dev Sustain. https:// doi.org/10.1007/s10668-019-00531-0

6. Maliqi E, Jusufi K, Singh SK (2020) Assessment and spatial mapping of groundwater quality parameters using metal pollution indices, graphical methods and geoinformatics. Anal Chem Lett 10(2):152-180

7. Delpla I, Proulx F, Rodriguez MJ (2020) A methodology to prioritize spatio-temporal monitoring of drinking water quality considering population vulnerability. J Environ Manag 255:109869

8. Saeedi $\mathrm{M}$ et al (2010) Development of groundwater quality index. Environ Monit Assess 163(1-4):327-335

9. Jain R (2011) Providing safe drinking water: a challenge for humanity. Clean Technol Environ Policy 14(1):1-4

10. Shil S, Singh UK, Mehta P (2019) Water quality assessment of a tropical river using water quality index (WQI), multivariate statistical techniques and GIS. AppI Water Sci 9(7):168

11. Adimalla N, Qian H (2019) Groundwater quality evaluation using water quality index (WQI) for drinking purposes and human health risk (HHR) assessment in an agricultural region of Nanganur, south India. Ecotoxicol Environ Saf 176:153-161

12. Amadi AN et al (2014) Quality assessment of soil and groundwater near Kaduna Refinery and Petrochemical Company, Northwest Nigeria. J Sci Res Rep 3(6):884-893

13. Anawar HM, Akai J, Sakugawa H (2004) Mobilization of arsenic from subsurface sediments by effect of bicarbonate ions in groundwater. Chemosphere 54(6):753-762

14. Anudu GK et al (2011) Hydro-geochemical evaluation of groundwater resources from hand-dug wells around Kakuri and Its Environs, Kaduna State, Northcentral Nigeria. J Min Geol 47(2):75-85

15. Bora M, Goswami DC (2016) Water quality assessment in terms of water quality index (WQI): case study of the Kolong River, Assam, India. Appl Water Sci 7(6):3125-3135

16. Chae G-T et al (2006) Hydrogeochemistry of sodium-bicarbonate type bedrock groundwater in the Pocheon Spa Area, South Korea: water-rock interaction and hydrologic mixing. J Hydrol 321(1-4):326-343

17. Das S, Nag SK (2015) Deciphering groundwater quality for irrigation and domestic purposes - a case study in Suri I and Il blocks, Birbhum District, West Bengal, India. J Earth Syst Sci 124(5):965-992

18. Faruruwa M, Titilayo O (2017) Physico-chemical, heavy metals and radioisotope concentrations in underground water from Kaduna, Kafanchan and Zaria Senatorial Areas of Kaduna State, Nigeria. Chem Sci Int J 20(4):1-12

19. Haritash AK et al (2008) Suitability assessment of groundwater for drinking, irrigation and industrial use in some North Indian villages. Environ Monit Assess 145(1-3):397-406 
20. Patil VBB et al (2020) Multivariate statistics and water quality index (WQI) approach for geochemical assessment of groundwater quality-a case study of Kanavi Halla Sub-Basin, Belagavi, India. Environ Geochem Health 42(9):2667-2684

21. Rakotondrabe F et al (2017) Assessment of surface water quality of Bétaré-Oya gold mining area (East-Cameroon). J Water Resour Prot 09(08):960-984

22. Sener S, Sener E, Davraz A (2017) Evaluation of water quality using water quality index (WQI) method and GIS in Aksu River (SW-Turkey). Sci Total Environ 584-585:131-144

23. Zhu XM et al (2019) Hydrochemical properties and groundwater quality evaluation in Suzhou City, lower Yangtze Delta, China. IOP Conf Ser Earth Environ Sci 344:1-12

24. Jacintha TGA et al (2016) Hydrogeochemical characterization of groundwater of peninsular Indian region using multivariate statistical techniques. Appl Water Sci 7(6):3001-3013

25. Jatau BS, Fadele SI, Agelaga AG (2013) Groundwater investigation in parts of Kaduna South and environs using wenner offset method of electrical resistivity sounding. J Earth Sci Geotech Eng 3(1):41-54

26. Olaniyan IO, Ogwuche EU, Olorunaiye ES (2012) Groundwater contamination from septic tanks in selected part of Kaduna, Nigeria. Researcher 7(7):1-6

27. Olaniyan IO, Tsuzom JN (2014) An appraisal of certain characteristics of aquifer in Chikun Local Government Area of Kaduna, Nigeria. Int J Eng Sci Adv Technol 4(6):554-559

28. Owolabi O, Okafo C, Nwude M (2016) Cumulative uncertainty in measured groundwater iron content of Rigasa Watershed, Kaduna. Brit J Appl Sci Technol 14(1):1-11

29. Saminu A et al (2016) Effects of landfill leachate on groundwater quality of Unguwan Dosa, Kaduna. Acad J Sci Eng 10(1):64-71

30. Saminu A, Mohammed ISA, Elanu C (2019) Comparative assessment of the quality of ground and surface water for irrigation in Mando, Kaduna, Nigeria. Am J Eng Res 8(4):28-31

31. Chaturvedi MK, Bassin JK (2010) Assessing the water quality index of water treatment plant and bore wells, in Delhi, India. Environ Monit Assess 163(1-4):449-453

32. Das Kangabam R et al (2017) Development of a water quality index (WQI) for the Loktak Lake in India. Appl Water Sci 7(6):2907-2918

33. Krishna Kumar S et al (2014) Hydro-geochemistry and application of water quality index (WQI) for groundwater quality assessment, Anna Nagar, part of Chennai City, Tamil Nadu, India. Appl Water Sci 5(4):335-343

34. Lermontov A et al (2009) River quality analysis using fuzzy water quality index: Ribeira do Iguape River watershed, Brazil. Ecol Indic 9(6):1188-1197

35. Lumb A, Sharma TC, Bibeault JF (2011) A review of genesis and evolution of water quality index (WQI) and some future directions. Water Qual Expos Health 3(1):11-24

36. Sánchez $\mathrm{E}$ et al (2007) Use of the water quality index and dissolved oxygen deficit as simple indicators of watersheds pollution. Ecol Ind 7(2):315-328

37. Folorunsho JO et al (2014) A comparison of ANFIS and ANNbased models in river discharge forecasting. New Ground Res J Phys Sci 1(1):1-16

38. Okafor GC, Ogbu KN (2018) Assessment of the impact of climate change on the freshwater availability of Kaduna River basin, Nigeria. J Water Land Dev 38(1):105-114

39. Offodile ME (2002) Groundwater study and development in Nigeria, 2nd edn. Mecon Geological and Engineering, Ltd Ehinder O, Jos, p 453

40. Aizebeokhai AP, Oyeyemi KD (2017) Geoelectrical characterisation of basement aquifers: the case of Iberekodo, southwestern Nigeria. Hydrogeol J 26(2):651-664
41. Akinwumiju AS, Olorunfemi MO (2019) Development of a conceptual groundwater model for a complex basement aquifer system: the case OF OSUN drainage basin in southwestern Nigeria. J Afr Earth Sci 159(103574):1-19

42. Ashaolu ED et al (2020) Spatial and temporal recharge estimation of the basement complex in Nigeria, West Africa. J Hydrol Reg Stud 27(100658):1-19

43. Obada EM, Olaniyan IO (2013) Groundwater quality appraisal in southern parts of Kaduna State, Nigeria. Am J Environ Eng 3(1):77-83

44. Allamin IA et al (2015) Physicochemical and bacteriological analysis of well water in Kaduna Metropolis. Kaduna State OALib 02(06):1-5

45. Jatau BS, Bajeh I, Innocent S (2008) Trace metal in surface and subsurface water in Kaduna South Industrial Area Northcentral Nigeria. Res J Appl Sci 3(1):81-87

46. Joseph OA (2018) Aquifer vulnerability to surface contamination: a case of the new millennium city, Kaduna, Kaduna State Nigeria. World J Appl Phys 3(1):1

47. Kenneth KT, Terna IO, Amen OC (2015) Impact of urban livestock production on groundwater quality in Kaduna Metropolis, Nigeria. Am J Water Resour 3(4):109-117

48. Yidana SM et al (2018) Evolutionary analysis of groundwater flow: application of multivariate statistical analysis to hydrochemical data in the Densu Basin, Ghana. J Afr Earth Sci 138:167-176

49. Landwehr JM, Deininger RA, Harkins RD (1974) An objective water quality index. Water Pollut Control Fed 46(7):1804-1809

50. Brown RM et al (1972) A water quality indexcrashing the psychological barrier. In: Thomas WA (ed) Indicators of environmental quality. Plenum Press, New York, pp 173-182

51. Mukate $S$ et al (2019) Development of new integrated water quality index (IWQI) model to evaluate the drinking suitability of water. Ecol Ind 101:348-354

52. Haritash AK, Gaur S, Garg S (2016) Assessment of water quality and suitability analysis of River Ganga in Rishikesh, India. Appl Water Sci 6(4):383-392

53. Ryznar JW (1944) A new index for determining amount of calcium carbonate scale formed by a water. American Water Works Association, Denver

54. Langelier WF (1936) The analytical control of anti-corrosion water treatment. J Am Water Works Assoc 28(10):1500-15-21

55. Alias $\mathrm{N}$ et al (2014) Sectional analysis of the pollutant washoff process based on runoff hydrograph. J Environ Manag 134:63-69

56. Kokot $\mathrm{S}$ et al (1998) Data interpretation by some common chemometrics methods. Electroanalysis 10(16):1081-1088

57. Hildebrandt A et al (2008) Impact of pesticides used in agriculture and vineyards to surface and groundwater quality (North Spain). Water Resour 42:3315-3326

58. Machiwal D, Jha MK (2015) Identifying sources of groundwater contamination in a hard-rock aquifer system using multivariate statistical analyses and GIS-based geostatistical modeling techniques. J Hydrol Reg Stud 4:80-110

59. Egbueri JC (2020) Groundwater quality assessment using pollution index of groundwater (PIG), ecological risk index (ERI) and hierarchical cluster analysis (HCA): a case study. Groundw Sustain Dev 10(100292):1-8

60. Subba Rao N, Chaudhary M (2019) Hydrogeochemical processes regulating the spatial distribution of groundwater contamination, using pollution index of groundwater (PIG) and hierarchical cluster analysis (HCA): a case study. Groundw Sustain Dev 9(100238):1-14

61. Gibbs RJ (1970) Mechanisms controlling world water chemistry. Sci New Seri 170(3962):1088-1090 
62. Wali SU et al (2019) Hydrochemical characterization of shallow and deep groundwater in Basement Complex areas of southern Kebbi State, Sokoto Basin, Nigeria. Appl Water Sci 9(169):1-36

63. Ismail AH, Hassan G, Sarhan A-H (2020) Hydrochemistry of shallow groundwater and its assessment for drinking and irrigation purposes in Tarmiah district, Baghdad Governorate, Iraq. Groundw Sustain Dev 10:1-12

64. Marandi A, Shand P (2018) Groundwater chemistry and the Gibbs diagram. Appl Geochem 97:209-212

65. Rashid A et al (2019) Geochemical modeling, source apportionment, health risk exposure and control of higher fluoride in groundwater of sub-district Dargai, Pakistan. Chemosphere 243:125409

66. Ravikumar P, Somashekar RK (2015) Principal component analysis and hydrochemical facies characterization to evaluate groundwater quality in Varahi river basin, Karnataka state, India. Appl Water Sci 7(2):745-755

67. Torres-Martínez JA et al (2020) Tracking nitrate and sulfate sources in groundwater of an urbanized valley using a multitracer approach combined with a Bayesian isotope mixing model. Water Res 182(115962):1-16

68. Ahmad Z, Qadir A (2011) Source evaluation of physicochemically contaminated groundwater of Dera Ismail Khan area, Pakistan. Environ Monit Assess 175(1-4):9-21

69. Akhtar MM, Tang Z (2013) Identification of contamination sources and TDS concentration in groundwater of second biggest city of Pakistan. Int J Environ Sci Dev 4:341-345

70. Emenike CP, Tenebe IT, Jarvis P (2018) Fluoride contamination in groundwater sources in Southwestern Nigeria: assessment using multivariate statistical approach and human health risk. Ecotoxicol Environ Saf 156:391-402

71. Jia $Y$ et al (2017) Sources of groundwater salinity and potential impact on arsenic mobility in the western Hetao Basin, Inner Mongolia. Sci Total Environ 601-602:691-702

72. Kebede $S$ et al (2005) Groundwater recharge, circulation and geochemical evolution in the source region of the Blue Nile River, Ethiopia. Appl Geochem 20(9):1658-1676

73. Li F et al (2007) Recharge source and hydrogeochemical evolution of shallow groundwater in a complex alluvial fan system, southwest of North China Plain. Environ Geol 55(5):1109-1122

74. Bekele B et al (2019) Sequestration of orthophosphate by $\mathrm{Ca}_{2} \mathrm{Al}-\mathrm{NO}_{3}$ layered double hydroxide-insight into reactivity and mechanism. Appl Clay Sci 176:49-57

75. Jalali M (2008) Phosphorous concentration, solubility and species in the groundwater in a semi-arid basin, southern Malayer, western Iran. Environ Geol 57(5):1011-1020

76. Jeevanandam M et al (2007) Hydrogeochemistry and groundwater quality assessment of lower part of the Ponnaiyar River Basin, Cuddalore district, South India. Environ Monit Assess 132(1-3):263-274

77. Khadse GK et al (2008) Qualitative evaluation of Kanhan river and its tributaries flowing over central Indian plateau. Environ Monit Assess 147(1-3):83-92

78. Vasanthavigar M et al (2010) Application of water quality index for groundwater quality assessment: Thirumanimuttar subbasin, Tamilnadu, India. Environ Monit Assess 171(1-4):595-609

79. Sorensen JP et al (2015) Emerging contaminants in urban groundwater sources in Africa. Water Res 72:51-63

80. Wang K, Sun D-W, Pu H (2017) Emerging non-destructive terahertz spectroscopic imaging technique: Principle and applications in the agri-food industry. Trends Food Sci Technol 67:93-105

81. Xu Y et al (2011) Occurrence of emerging organic contaminants in a tropical urban catchment in Singapore. Chemosphere 83(7):963-969
82. Abiodun AO, Manju S (2012) Correlations between calcium, magnesium and hardness of water in the drinking waters of Decatur County Georgia and the incidence of cardiovascular and cerebrovascular diseases, Georgia. J Sci 70(2):101-122

83. Hudak PF (2001) Water hardness and sodium trends in Texas aquifers. Environ Monit Assess 68:177-185

84. Arvidson RS, Mackenzie FT, Guidry MW (2013) Geologic history of seawater: a MAGic approach to carbon chemistry and ocean ventilation. Chem Geol 362:287-304

85. Wombacher F et al (2011) Magnesium stable isotope fractionation in marine biogenic calcite and aragonite. Geochim Cosmochim Acta 75(19):5797-5818

86. MacAdam J, Parsons SA (2004) Calcium carbonate scale formation and control. Rev Environ Sci Bio/Technol 3:159-169

87. Hoseinzadeh E et al (2013) Evaluation of corrosion and scaling potential of a water treatment plant. Arch Hyg Sci 2(2):41-47

88. Tavanpour N, Noshadi M, Tavanpour N (2016) Scale formation and corrosion of drinking water pipes: a case study of drinking water distribution system of Shiraz City. Mod Appl Sci 10(3):166

89. Marion GM, Farren RE (1999) Mineral solubilities in the Na-K$\mathrm{Mg}-\mathrm{Ca}-\mathrm{Cl}-\mathrm{SO}_{4}-\mathrm{H}_{2} \mathrm{O}$ system: a re-evaluation of the sulfate chemistry in the Spencer-Møller-Weare model. Geochim Cosmochim Acta 63(9):1305-1318

90. Shih W-Y et al (2005) Morphometric characterization of calcium sulfate dihydrate (gypsum) scale on reverse osmosis membranes. J Membr Sci 252(1-2):253-263

91. Jakóbczyk-Karpierz S et al (2017) Geochemical and isotopic study to determine sources and processes affecting nitrate and sulphate in groundwater influenced by intensive human activity_carbonate aquifer Gliwice (southern Poland). Appl Geochem 76:168-181

92. EPA (2001) Parameters of water quality: Interpretation and Standards. An Ghniomhaireacht um Chaomhnu Comhshaoil. Ireland, 132

93. Adanu EA (1991) Source and recharge of groundwater in the basement terrain in the Zaria-Kaduna area, Nigeria: applying stable isotopes. J Afr Earth Sci 13(2):229-234

94. Alagbe $S$ (2002) Groundwater resources of River Kan Gimi Basin, north-central, Nigeria. Environ Geol 42(4):404-413

95. Akpan AE, Ugbaja AN, George NJ (2013) Integrated geophysical, geochemical and hydrogeological investigation of shallow groundwater resources in parts of the Ikom-Mamfe Embayment and the adjoining areas in Cross River State, Nigeria. Environ Earth Sci 70:1435-1456

96. Raji BA, Alagbe SA (1997) Hydrochemical facies in parts of the Nigerian basement complex. Environ Geol 29(1/2):46-49

97. Ogundana AK, Aladejana JA (2014) Geophysical and hydrochemical evaluation of springwater potential and quality within the Basement Complex of Southwestern Nigeria. Int J Eng Sci 3(5):45-55

98. Gautam SK et al (2018) Environmental monitoring of water resources with the use of PoS index: a case study from Subarnarekha River basin India. Environ Earth Sci 77(70):1-17

99. Moharir K et al (2019) Spatial interpolation approach-based appraisal of groundwater quality of arid regions. J Water Supply Res Technol Aqua 68(6):431-447

100. Hussain I et al (2014) Distribution of total dissolved solids in drinking water by means of Bayesian Kriging and Gaussian spatial predictive process. Water Qual Expos Health 6(4):177-185

101. Jayasekera DL, Kaluarachchi JJ, Villholth KG (2011) Groundwater stress and vulnerability in rural coastal aquifers under competing demands: a case study from Sri Lanka. Environ Monit Assess 176(1-4):13-30

102. Sappa $G$ et al (2015) Effects of seasonal change and seawater intrusion on water quality for drinking and irrigation purposes, 
in coastal aquifers of Dar es Salaam, Tanzania. J Afr Earth Sci 105:64-84

103. Fytianos K, Christophoridis C (2004) Nitrate, arsenic and chloride pollution of drinking water in Northern Greece. Elaboration by applying GIS. Environ Monit Assess 93:55-67

104. DVGW, Nitrate occurrence in drinking water. https://www. dvgw.de/english-pages/topics/water/nitrates-and-drinkingwater/. Retrieved on 26/02/2020, 2020: p. 1-4.

105. Petersen GW, Chesters G, Lee GB (1966) Quantitative determination of calcite and dolomite in soils. J Soil Sci 17(2):328-338

106. Robert LF (1974) The natural history of crystalline calcium carbonate: effect of magnesium content and salinity. J Sedim Petrol 44(1):40-53

107. Christine MS, Bruce HW, Donald RP (1984) Rock composition, dolomite stoichiometry, and rock/water reactions in dolomitic carbonate rocks. J Geol 96(6):609-622

108. Jimoh OA et al (2017) Synthesis of precipitated calcium carbonate: a review. Carb Evap 33(2):331-346

109. Phan TT et al (2019) Rare earth elements and radiogenic strontium isotopes in carbonate minerals reveal diagenetic influence in shales and limestones in the Appalachian Basin. Chem Geol 509:194-212

110. Zahn MT, Grimm W (1993) Nitrate and chloride loadings as anthropogenic indicators. Water Air Soil Pollut 68:469-483

111. Rouabhia A et al (2008) Impact of human activities on quality and geochemistry of groundwater in the Merdja area, Tebessa, Algeria. Environ Geol 56(7):1259-1268

112. Thunqvist EL (2004) Regional increase of mean chloride concentration in water due to the application of deicing salt. Sci Total Environ 325(1-3):29-37

113. Lin CY et al (2012) Delineation of temporal variability and governing factors influencing the spatial variability of shallow groundwater chemistry in a tropical sedimentary island. J Hydrol 432-433:26-42

114. Wali SU et al (2018) Evaluation of Shallow Groundwater in Cretaceous and Tertiary Aquifers of Northern Kebbi State, Nigeria. SF J Environ Earth Sci 1(1):1-11

115. Wali SU et al (2018) Groundwater Hydrochemical characterization in urban areas of Southwestern Sokoto Basin Nigeria. SF J Environ Earth Sci 1(1):1-17

116. Wali SU et al (2020) Reassessing groundwater potentials and subsurface water hydrochemistry in a Tropical Anambra Basin, Southeastern Nigeria. J Geol Res 2(3):1-24

117. Wali SU et al (2020) Re-examination of hydrochemistry and groundwater potentials of Cross River and Imo-Kwa-lbo intersecting Tropical Basins of South-South Nigeria. J Geol Res 2(3):25-42

118. Wali SU et al (2020) Review of groundwater potentials and groundwater hydrochemistry of semi-arid Hadejia-Yobe Basin, North-eastern Nigeria. J Geol Res 2(2):20-33

119. Usman AA et al (2020) Examination of surface water along river-Rima floodplain in Wamakko, Sokoto State, Nigeria. J Geol Res 2(3):43-51

120. Wali SU, Alias N (2020) Multi-pollutant approach to model contaminants flow in surface and groundwater: a review. IOP Conf Ser Mater Sci Eng 884:012030

Publisher's Note Springer Nature remains neutral with regard to jurisdictional claims in published maps and institutional affiliations. 